NBER WORKING PAPER SERIES

\title{
BANK-BASED OR MARKET-BASED FINANCIAL SYSTEMS: WHICH IS BETTER?
}

\author{
Ross Levine \\ Working Paper 9138 \\ http://www.nber.org/papers/w9138 \\ NATIONAL BUREAU OF ECONOMIC RESEARCH \\ 1050 Massachusetts Avenue \\ Cambridge, MA 02138 \\ September 2002
}

I thank Daron Acemoglu, Franklin Allen, Maria Carkovic, Nicola Cetorelli, Karla Hoff, Kevin Kordana, Naomi Lamoreaux, Norman Loayza, Patrick Bolton, Raghuram Rajan, Rene Stulz, Anjan Thakor, two anonymous referees, and seminar participants at the University of Michigan, Banco Central de Chile, Federal Reserve Bank of Chicago, Stanford University, University of Virginia School of Law, and the World Bank for helpful comments. The views expressed in this paper are those of the authors and not necessarily those of the National Bureau of Economic Research.

(C) 2002 by Ross Levine. All rights reserved. Short sections of text, not to exceed two paragraphs, may be quoted without explicit permission provided that full credit, including $(\mathbb{C}$ notice, is given to the source. 
Bank-Based or Market-Based Financial Systems: Which is Better?

Ross Levine

NBER Working Paper No. 9138

September 2002

JEL No. G0, K2, O4

\section{$\underline{\text { ABSTRACT }}$}

For over a century, economists and policy makers have debated the relative merits of bank-based versus market-based financial systems. Recent research, however, argues that classifying countries as bank-based or market is not a very fruitful way to distinguish financial systems. This paper represents the first broad, cross-country examination of which view of financial structure is more consistent with the data. The results indicate that although overall financial development is robustly linked with economic growth, there is no support for either the bank-based or market-based view.

Ross Levine

Finance Department, Room 3-257

Carlson School of Management

University of Minnesota

321 19th Aveneu South

Minneapolis, MN 55455

and NBER 


\section{Introduction}

This paper empirically assesses competing theoretical views on a century old policy debate: Are bank-based or market-based financial systems better for promoting long-run economic growth? Since the $19^{\text {th }}$ century, many economists have argued that bank-based systems are better at mobilizing savings, identifying good investments, and exerting sound corporate control, particularly during the early stages of economic development and in weak institutional environments. Others, however, emphasize the advantages of markets in allocating capital, providing risk management tools, and mitigating the problems associated with excessively powerful banks. Economists have constructed a vast number of theoretical insights into the comparative advantages of different financial systems. ${ }^{1}$ Reflecting these schisms, policymakers continue to struggle with the relative merits of bank-based versus market-based financial systems in making policy decisions. Thus, the objective of this paper is to produce empirical evidence that (1) distinguishes among competing theories and (2) helps policy makers design appropriate financial sector reform strategies.

Empirical research on the comparative merits of bank-based and market-based financial systems has centered on Germany and Japan as bank-based systems and the United States and the United Kingdom as market-based systems. ${ }^{2}$ This work has produced illuminating insights into the functioning of these financial systems. Nonetheless, it is difficult to draw broad conclusions about the long-run growth effects of bank-based and market-based financial systems based on only four countries, especially four countries that have very similar long-run growth rates. Although these countries together account for over 50 percent of world output and although there are decades during which their growth rates diverged substantially, broadening the analysis to a wider array of national experiences will provide greater information on the bank-based versus market-based debate. Consequently, this paper constructs a new dataset to investigate the relationship between economic growth and the degree to which countries are bank-based or market-based. 
In conducting the first, broad cross-country study of financial structure and economic growth, this paper provides empirical evidence on competing theories of financial structure. The bank-based view highlights the positive role of banks in (i) acquiring information about firms and managers and thereby improving capital allocation and corporate governance (Diamond, 1984; Ramakrishnan and Thakor, 1984), (ii) managing cross-sectional, intertemporal, and liquidity risk and thereby enhancing investment efficiency and economic growth (Allen and Gale, 1999; Bencivenga and Smith, 1991), and (iii) mobilizing capital to exploit economies of scale (Sirri and Tufano, 1995). The bank-based view also stresses the shortcomings of market-based systems. Stiglitz (1985), for instance, argues that welldeveloped markets quickly and publicly reveal information, which reduces the incentives for individual investors to acquire information. Banks, however, mitigate this problem since they form long-run relationships with firms and do not reveal information immediately in public markets (Boot, Greenbaum, and Thakor, 1993). Also, Boot and Thakor (1997) argue that banks - as coordinated coalitions of investors - are better than uncoordinated markets at monitoring firms and reducing post-lending moral hazard (asset substitution). Proponents of the bank-based view also stress that liquid markets create a myopic investor climate (Bhide 1993). In liquid markets, investors can inexpensively sell their shares, so that they have fewer incentives to exert rigorous corporate control. Thus, according to the bank-base view, greater market development may hinder corporate control and economic growth. Furthermore, Gerschenkron (1962) and Rajan and Zingales (1998) stress that powerful banks can more effectively force firms to re-pay their debts than atomistic markets, especially in countries with weak contract enforcement capabilities. Without powerful banks to force repayment, therefore, external investors may be reluctant to finance industrial expansion in countries with underdeveloped institutions. Thus, the bank-based view holds that banks -- unhampered by regulatory restrictions on their activities -- can exploit scale economies in information processing, ameliorate moral hazard through effective monitoring, form long-run relationships with firms to ease asymmetric information distortions, and thereby boost economic growth. In contrast, the market-based view highlights the growth enhancing role of well-functioning markets in (i) fostering greater incentives to research firms since it is easier to profit from this information 
by trading in big, liquid markets (Holmstrom and Tirole, 1993), (ii) enhancing corporate governance by easing takeovers and making it easier to tie managerial compensation to firm performance (Jensen and Murphy, 1990), and (iii) facilitating risk management (Levine, 1991; Obstfeld, 1994). Moreover, the market-based view stresses problems with banks. Specifically, powerful banks can stymie innovation by extracting informational rents and protecting established firms with close bank-firm ties from competition (Hellwig, 1991; Rajan, 1992). Furthermore, powerful banks with few regulatory restrictions on their activities may collude with firm managers against other creditors and impede efficient corporate governance (Hellwig, 1998; Wenger and Kaserer, 1998). In contrast, competitive capital markets play a positive role in aggregating diffuse information signals and effectively transmitting this information to investors, with beneficial implications for firm financing and economic performance (Boot and Thakor, 1997; Allen and Gale, 1999). Thus, proponents of the market-based view stress that markets will reduce the inherent inefficiencies associated with banks and enhance economic growth. ${ }^{3}$

The financial services view -- as articulated by Merton and Bodie (1995) and Levine (1997) minimizes the importance of the bank-based versus market-based debate. It stresses that financial arrangements - contracts, markets, and intermediaries - arise to ameliorate market imperfections and provide financial services. That is, financial arrangements arise to assess potential investment opportunities, exert corporate control, facilitate risk management, enhance liquidity, and ease savings mobilization. By providing these financial services more or less effectively, different financial systems promote economic growth to a greater or lesser degree. According to this view, the main issue is not banks or markets. The issue is creating an environment in which intermediaries and markets provide sound financial services. Conceptually, the financial services view is fully consistent with both the bankbased and market-based views. Nevertheless, the financial services view places the analytical spotlight on how to create better functioning banks and markets, and relegates the bank-based versus market-based debate to the shadows.

A special case of the financial-services view when applied to the bank-based versus market-based debate is the law and finance view (La Porta, Lopez-de-Silanes, Shleifer, and Vishny, henceforth LLSV, 
1998). As stated by LLSV (2000, p. 19), “... bank- versus market-centeredness is not an especially useful way to distinguish financial systems." Rather, these authors highlight the role of the legal system in creating a growth-promoting financial sector. The law and finance view argues that finance is a set of contracts. These contracts are defined - and made more or less effective - by legal rights and enforcement mechanisms. From this perspective, a well-functioning legal system facilitates the operation of both markets and intermediaries. It is the overall level and quality of financial services - as determined by the legal system - that improves the efficient allocation of resources and economic growth. While focusing on legal systems is not inconsistent with banks or markets playing a particularly important role in stimulating economic growth, LLSV (2000) clearly argue that laws and enforcement mechanisms are a more useful way to distinguish financial systems than focusing on whether countries are bank-based of market-based.

An important contribution of this paper is the construction of a broad cross-country dataset to examine market- and bank-based financial systems. Past empirical research primarily involves rigorous country-studies and uses country-specific measures of financial structure. Thus, studies of Germany commonly focus on the extent to which banks own shares or vote proxy shares. Studies of Japan frequently focus on whether a company has a "main bank." Studies of the United States sometimes concentrate on the role of market takeovers as corporate control devices. These country-specific measures are very useful; however, they are difficult to use in a broad cross-country analysis. This paper uses data from individual country publications, international agencies, and a recent survey of national regulatory authorities to measure financial structure. One advantage of the broad cross-country approach is that it permits a consistent treatment of financial system structure across many countries. ${ }^{4}$ Second, the cross-country approach circumvents the problem noted earlier: if one accepts that Germany and Japan are bank-based and that the United States and the United Kingdom are market-based, then this implies that financial structure did not matter much since the four countries have very similar long-run growth rates. ${ }^{5}$ This paper incorporates countries with very different financial systems and growth rates. The dataset measures the size, activity, and efficiency of various components of the financial system, including banks, 
securities markets, and nonbank financial intermediaries for a wide assortment of developed and developing countries. The paper also measures financial structure by using new data on regulatory restrictions on bank activities and the ability of banks to own and control firms. While recognizing that broad cross-country comparisons come at the cost of less precise measures of financial structure, this paper provides the first consistent appraisal of financial structure and economic performance in the international cross-section of countries.

The results are overwhelming. There is no cross-country empirical support for either the marketbased or bank-based views. Neither bank-based nor market-based financial systems are particularly effective at promoting growth. The results are robust to an extensive array of sensitivity analyses that employ different measures of financial structure, alternative statistical procedures, and different datasets. The conclusions are also not altered when looking at extremes: countries with very well developed banks but poorly developed markets do not perform notably differently from those with very well developed markets but poorly developed banks, or than those with more balanced financial systems. I also allow for the possibility that financial structure changes as countries develop and legal systems evolve. For instance, Boyd and Smith (1998) develop a model in which countries become more market-based, with positive implications for economic growth, as they develop. Rajan and Zingales (1998) argue that bankbased systems are better at promoting growth in countries with poor legal systems, while market-based systems have advantages as legal systems improve. Allowing for these possibilities, however, does not alter this paper's conclusion: cross-country comparisons do not suggest that distinguishing between bankbased and market-based is analytically useful for understanding the process of economic growth.

The cross-country evidence is consistent with the financial services view. Better-developed financial systems positively influence economic growth. It is relatively unimportant for economic growth, however, whether overall financial development stems from bank or market development. More particularly, the data are consistent with the view that the legal system plays a leading role in determining the level of growth-promoting financial services. The component of financial development defined by the legal rights of investors and the efficiency of contract enforcement is very strongly associated with 
growth. Thus, the data tend to support the LLSV (1999) view that (i) the legal system crucially determines financial development and (ii) financial structure is not a particularly useful way to distinguish financial systems. The results do not support public policies aimed at creating a particular mixture of financial markets and intermediaries. Rather, the results highlight the importance of strengthening the rights of investors and improving the efficiency of contact enforcement. While there are difficulties in measuring financial structure, this paper uses an exhaustive number of indicators that all tell the same story: it is less useful to distinguish financial systems by whether they are bank-based or market-based than it is to focus on the specific laws and enforcement mechanisms that govern both debt and equity transactions.

The remainder of this paper is organized as follows. Section II presents the econometric specification and the data are discussed in Section III. Section IV provides the regression results and Section V conclusions 


\section{Econometric Specification}

The bank-based, market-based, financial services, and law and finance views of financial structure can be represented as rival predictions on the parameters in a standard growth equation. Standard growth models and their econometric representations typically model real per capita GDP growth, G, as a function of a number of growth determinants, X. These growth determinants universally include initial income and the initial level of workforce education to capture conditional convergence and the importance of human capital. Many models also control for macroeconomic stability, openness to international trade, and political stability. I modify these cross-country growth specifications to investigate econometrically the competing views of financial structure.

Consider the following cross-country regression equations

$$
\begin{aligned}
& \mathrm{G}=\mathrm{a}^{\prime} \mathrm{X}+\mathrm{bS}+\mathrm{U}(1) \\
& \mathrm{G}=\mathrm{c}^{\prime} \mathrm{X}+\mathrm{dF}+\mathrm{U}(2) \\
& \mathrm{G}=\mathrm{f}^{\prime} \mathrm{X}+\mathrm{hS}+\mathrm{jF}+\mathrm{U}(3)
\end{aligned}
$$

$\mathrm{G}$ is real per capita GDP growth.

$\mathrm{X}$ is a set of conditioning information, i.e., standard growth determinants.

$\mathrm{S}$ measures financial structure. Larger values of $\mathrm{S}$ signify more market-based, while smaller values signify more bank-based.

F measures overall financial sector development, i.e., the level of development of banks, nonbanks, and securities markets. Larger values of $F$ signify a greater level of financial services.

$\mathrm{U}(\mathrm{i})$ is the error term in equation $\mathrm{i}=1,2$, and 3 respectively.

The small letters, a, b, c, d, f, h, and $\mathrm{j}$ are coefficients.

Different hypotheses regarding financial structure and growth imply different predictions on the values of the parameters in regressions (1)-(3).

Bank-based view: Bank-based systems are particularly good for growth and banks contribute to overall financial development. Thus, the bank-based view predicts that $\mathrm{b}<0, \mathrm{~d}>0, \mathrm{~h}<0$, and $\mathrm{j}>0$. This is a narrow conception of the bank-based view. A broader approach is explained and tested below

Market-based view: Market-based systems are particularly good for growth and markets contribute to overall financial development. Thus, the market-based view predicts that $b>0, d>0, h>0$, and $j>0$. 
Financial-services view: Financial services - whether provided by bank or markets -- positively influence growth. Thus, the financial-services view predicts that $\mathrm{d}>0$, and $\mathrm{j}>0$.

Law and finance view: The law and finance view is a special case of the financial-services view. It predicts that the component of overall financial development defined by the legal system is critical for long-run economic growth, but having a bank-based or market-based financial system per se is not critical for growth. Moreover, the law and finance view predicts that the legal system matters primarily by influencing overall financial sector performance. To assess the law and finance view, I use instrumental variables to extract that component of overall financial development, F, defined by the legal rights of outside investors and the efficiency of contract enforcement. Then, I assess whether this component of financial development is robustly linked with economic growth. I also examine whether the legal system variables directly explain growth and whether they explain growth beyond their ability to explain crosscountry differences in F, overall financial development. Econometrically, the law and finance view makes the same predictions as the financial-services view, except within the context of a regression framework that uses the legal codes and enforcement efficiency variables as instruments.

Hybrid views: An important set of views on the market-based and bank-based debate argue that banks are important for growth under some conditions while markets are more important under alternative conditions.

First, Boyd and Smith (1998) suggest that banks are particularly important at low levels of economic development. As income rises, however, countries benefit from becoming more market-based. This view suggests that the regression should be specified as follows, where $\mathrm{Y}$ is real per capita GDP.

$$
\mathrm{G}=\mathrm{a}^{\prime} \mathrm{X}+\mathrm{bS}+\mathrm{kS} * \mathrm{Y}+\mathrm{U}(4)
$$

This view predicts that $\mathrm{b}<0$ and $\mathrm{k}>0$. I consider this below.

Second, Rajan and Zingales (1998) argue that bank-based systems have a comparative advantage in economies with weak legal systems. In those countries with weak institutions, powerful banks can still force firms to reveal information and pay their debts. According to this view, economies will benefit from becoming more market-based only as their legal system capabilities strengthen. This 
view suggests that the regression should be specified as follows, where L is an index of legal system development.

$$
\mathrm{G}=\mathrm{a}^{\prime} \mathrm{X}+\mathrm{bS}+\mathrm{kS} \mathrm{S}^{*}+\mathrm{U}(5)
$$

This view predicts that $\mathrm{b}<0$ and $\mathrm{k}>0$. I consider this below.

\section{Data}

\section{A. Definitions of Financial Structure}

To examine the relationship between financial structure and growth, one needs a measure of financial structure. Unfortunately, there is no uniformly accepted definition of a bank-based or marketbased financial system. Consequently, I construct an assortment of measures for 48 countries over the 1980-95 period. All of these data are available on request. This is the largest set of countries for which I could get complete data. Most of the analyses involve pure cross-sectional analyses with one observation per country. The data appendix provides details.

One advantage of the broad cross-country approach is that it permits a consistent treatment of financial system structure across countries and thereby facilitates international comparisons. One weakness of the broad cross-country approach is that it does not permit the use of indicators such as the voting power of banks or the role of market takeovers as corporate control devices. These types of measures are not available for the cross-section of countries. To provide a broad cross-country approach, therefore, this paper focuses on four aggregate indicators of financial structure based on measures of the relative size, activity, and efficiency of banks and markets. I also use a measure of financial structure based on regulatory restrictions on the activities of banks. In considering the development of markets, I focus on stock markets because the International Finance Corporate collects accurate, consistent data for a broad cross-section of countries. I consider a wide array of alternative measures that I discuss below.

STRUCTURE-ACTIVITY is a measure of the activity of stock markets relative to that of

banks. To measure the activity of stock markets, I use the total value traded ratio, which equals the value of domestic equities traded on domestic exchanges divided by GDP. This total value traded ratio is 
frequently used to gauge market liquidity because it measures market trading relative to economic activity. To measure the activity of banks, I use the bank credit ratio, which equals the value of deposit money bank credits to the private sector as a share of GDP. Bank credit includes all deposit taking institutions as recognized by the International Monetary Fund. This measure excludes credits to the public sector (central and local governments as well as public enterprises). Thus, STRUCTURE-ACTIVITY equals the logarithm of the total value traded ratio divided by the bank credit ratio. Larger values of STRUCTURE-ACTIVITY imply a more market-based financial system. The values for STRUCTUREACTIVITY are ranked and listed in Table I. I discuss these values below.

STRUCTURE-SIZE is a measure of the size of stock markets relative to that of banks. To measure the size of the domestic stock market, I use the market capitalization ratio, which equals the value of domestic equities listed on domestic exchanges divided by GDP. To measure the size of bank, I again use the bank credit ratio. It should be noted, however, that other measures of banking system size, such as the total banking system assets divided by GDP, yield similar results. Thus, STRUCTURE-SIZE equals the logarithm of the market capitalization ratio divided by the bank credit ratio. The values for STRUCTURE-SIZE are ranked and listed in Table I. I discuss these values below.

STRUCTURE-EFFICIENCY is a measure of the efficiency of stock markets relative to that of banks. To measure the efficiency of stock markets, I use the total value traded ratio since it reflects the liquidity of the domestic stock market. I also used the turnover ratio, which equals the value of stock transactions relative to market capitalization. The turnover ratio measures trading relative to the size of the markets and is also used as an indicator of market efficiency. Using the turnover ratio produces similar results to those obtained with the total value traded ratio. To measure the efficiency of the banking sector, I use overhead costs, which equals the overhead costs of the banking system relative to banking system assets. Large overhead costs may reflect inefficiencies in the banking system. There are potential problems with this measure, however. Overhead costs may capture efficient investments in banking, not inefficiencies. While many readers may question the accuracy of this index, I include it for completeness. I also used interest rate margins in place of overhead costs and obtained similar results. 
Thus, STRUCTURE-EFFICIENCY equals the logarithm of the total value traded ratio times overhead costs. Larger values of STRUCTURE-EFFICIENCY imply a more market-based financial system. Its value is given in Table I.

STRUCTURE-AGGREGATE is a conglomerate measure of financial structure based on activity, size, and efficiency. Specifically STRUCTURE-AGGREGATE is the first principal component of STRUCTURE-ACTIVITY, STRUCTURE-SIZE, and STRUCTURE-EFFICIENCY. Thus, I construct STRUCTURE-AGGREGATE to be the variable that best explains (highest joint R-square) the first three financial structure indicators. The ranked values of this variable are also given in Table I.

STRUCTURE-REGULATORY is an aggregate measure of regulatory restrictions on commercial bank activities. Based on a two-year survey of national regulatory authorities, I have information on the degree to which national regulatory authorities allow commercial banks to engage in securities (securities underwriting, brokering, dealing, and all aspects of the mutual fund industry), insurance (insurance underwriting and selling), or real estate (real estate investment, development, and management) activities and the extent to which banks can own and control nonfinancial firms. ${ }^{6}$ Specifically, for the three regulatory categories on activities, I assign four possible values: 1 if the activity is unrestricted (A full range of activities in the given category can be conducted directly in the commercial bank); 2 if the activity is permitted (a full range of activities can be conducted, but all or some must be conducted in subsidiaries); 3 if the activity is restricted (less than a full range of activities can be conducted in the bank or subsidiaries); and 4 if the activity is prohibited in the bank or subsidiaries. In terms of banks owning nonfinancial firms, this variable takes on the value 1 if ownership is unrestricted (bank may own 100\% of the equity in any nonfinancial firm), 2 if ownership is permitted (bank may own $100 \%$ of the equity in a nonfinancial firm, but ownership is limited based on a bank's equity capital.), 3 if ownership is restricted (bank can only acquire less than $100 \%$ of the equity in a nonfinancial firm), and 4 if commercial bank ownership of nonfinancial firms is prohibited 
Table I lists values of STRUCTURE-REGULATORY, which is the summation of each of these four indicators of regulatory restrictions on commercial bank activities. I have examined each of the individual indicators and they produce the same conclusions as the aggregate index.

\section{B. Discussion of Financial Structure Measures}

The financial structure measures, especially the STRUCTURE-ACTIVITY indicator, produce intuitively appealing classifications of national financial systems, though it is important to highlight potential anomalies. The activity measure of financial structure, STRUCTURE-ACTIVITY, makes the intuitively attractive classification that Taiwan, Malaysia, Switzerland, and the United States are highly market-based because of their active markets. However, STRUCTURE-ACTIVITY also identifies Turkey, Mexico, and Brazil as very market-based even though their total value traded ratios are about one-sixth that of the United States. This reflects the fact that these countries all have extremely low levels of bank development.

The size measure of financial structure suffers from a large array of anomalies. The size measure of financial structure, STRUCTURE-SIZE, identifies Ghana, Jamaica, and Zimbabwe as having highly market-based financial systems. It does this because these countries have very small and underdeveloped banking systems, not because their stock markets are particularly well developed. The size measure also classifies Egypt and Honduras as highly bank-based, even though they have bank credit ratios below the sample mean. The size measure also indicates that Chile and South Africa are very market-based even though neither country has a very active market. Both countries have large market capitalization with relatively little trading. Many theories, however, focuses on market liquidity, not the listing of shares per se. Moreover, those models that emphasize the positive role of market size in disseminating and aggregating information presume the existence of a liquid market. Thus, the size measure seems particularly prone to problems.

STRUCTURE-EFFICIENCY identifies Switzerland, Taiwan, the United States, and the United Kingdom as market-based. It also indicates that Brazil has a relatively efficient market. Brazil has a high 
value of STRUCTURE-EFFICIENCY because it has very large bank overhead costs. Similarly, Egypt, Kenya, and Ghana standout as bank-based according to this efficiency measure, because they have very inefficient stock markets, not because they have efficient banks.

The STRUCTURE-REGULATORY variable provides a reasonably intuitive classification of countries. Some countries that are frequently classified as bank-based -- such as Austria, Germany, Switzerland, and France -- place very few restrictions on the activities of banks. Perhaps surprisingly, the United Kingdom and New Zealand also permit banks great latitude in securities activities, insurance activities, real estate activities, and in owning nonfinancial firms. In turn, the quintessential market-based economy, United States, imposed comparatively tight regulations on banks (prior to recent legislative changes). While STRUCTURE-REGULATORY is not highly correlated with the other financial structure indicators, we include it for completeness and to assess whether regulations on bank activities influence economic growth.

As exemplified, the activity, size, and efficiency financial structure measures can be large either because the country has well-developed markets, or because it has very poorly developed banks. Similarly, a country may have small financial structure indicators either because its banks are comparatively well-developed or because its markets are relatively underdeveloped. To assess whether this feature of the data is driving the results, I also identify countries with highly underdeveloped financial systems. Specifically, I identify those counties that have below median values of bank credit, market capitalization, and total value traded ratios and greater than median values of overhead expenditures. I create a dummy variable called UNDEVELOPED, which equals 1 if the country has below median values of all of these financial development indicators. Thus, rather than classifying countries as either bankbased or market-based, I first identify those countries with highly underdeveloped financial systems. ${ }^{7}$ As a robustness check, I test whether controlling for these countries in the regressions alters the findings and find that the findings are unaltered. ${ }^{8}$

The paper uses the best available data to assess the relationship between financial structure and economic growth. Although these indicators do not directly measure the degree to which bank influence 
industrial expansion or the ability of markets to fund innovative companies and facilitate risk management, the structure indicators - when taken together - provide a measure of the comparative role of banks and markets in the economy. As further evidence of the usefulness of these measures, Demirguc-Kunt and Levine (2001) show that countries with strong shareholder rights relative to creditor rights, strong accounting systems, and no deposit insurance tend to have more market-based financial systems. Thus, key legal and regulatory differences match-up with these financial structure measures. Furthermore, many of the individual components of the financial structure indicators (e.g., the bank credit and total value traded ratios) are robustly linked with growth and this link is not due to simultaneity or omitted variables bias (See Levine and Zervos, 1998; Levine, Loayza, and Beck, 2000; and Beck and Levine, 2002). Thus, I use these indicators to assess the relationship between economic performance and the degree to which countries are bank-based or market-based.

\section{Measuring Overall Financial Development}

The financial services views suggest that neither market-based nor bank-based categorizations are particularly important for identifying growth-enhancing financial systems. This section presents measures of overall financial sector development based on indicators of activity, size, and efficiency. The goal is that these indicators proxy for the degree to which national financial systems provide financial services: assessing firms and monitoring managers, easing risk management, and mobilizing resources. Table II lists these data.

FINANCE-ACTIVITY is a measure of the activity of stock markets and intermediaries. To measure the activity of stock markets, I use the total value traded ratio. To measure the activity of banks, I use the private credit ratio, which equals the value of financial intermediary credits to the private sector as a share of GDP. This measure excludes credits to the public sector (central and local governments as well as public enterprises). Unlike the bank credit ratio used to construct STRUCTURE-ACTIVITY, however, the private credit ratio includes credits issued by non-deposit money banks. Thus, it is a more comprehensive measure of financial intermediary development than private credit. This is appropriate since FINANCE-ACTIVITY is an overall index of financial sector activity. (Note, however, that when I 
reconstruct all the structure measures using private credit instead of bank credit, this does not change the results.) Thus, FINANCE-ACTIVITY equals the logarithm of the total value traded ratio times the private credit ratio. Also, Table III shows that FINANCE-ACTIVITY is significantly and positively correlated with each of the structure indicators and the other financial development indicators.

FINANCE-SIZE is a measure of the size of stock markets and intermediaries. To measure the size of the domestic stock market, I use the market capitalization ratio. As noted above, there are conceptual problems with simply using market size to gauge market development. Also, Levine and Zervos (1998) find that market size is not strongly linked with economic growth but market activity (as measured by the total value traded ratio) is a good predictor of economic growth. Nonetheless, we include this measure for completeness and to assess the Levine and Zervos (1998) finding with a different dataset. To measure the size of intermediaries, I again use the private credit ratio. Thus, FINANCE-SIZE equals the logarithm of the market capitalization ratio times the private credit ratio.

FINANCE-EFFICIENCY is a measure of financial sector efficiency. To measure the efficiency of stock markets, I use the total value traded ratio. To measure the efficiency of the banking sector, I use overhead costs, which equals the overhead costs of the banking system relative to banking system assets. Thus, FINANCE-EFFICIENCY equals the logarithm of the total value traded ratio divided by overhead costs.

FINANCE-AGGREGATE is the first principal component of the first three financial development indicators of activity, size, and efficiency.

\section{B. Other Variables}

To assess the independent relationship between growth and both financial structure and financial development, I control for other potential growth determinants (X in equations (1)-(5)). I use two sets of conditioning information.

The simple conditioning information set contains only the logarithm of initial real per capita GDP, which for the present study is the value in 1980, and the logarithm of the initial level of the number of years of schooling in the working age population. Initial income captures the convergence effect 
predicted by many growth models and schooling is included because many analyses suggest a positive role for human capital in the growth process.

The full conditioning information set contains the simple conditioning information set plus (i) the logarithm of one plus the average rate of inflation, (ii) the logarithm of one plus the average black market premium, (iii) the logarithm of government size as a share of GDP, (iv) the logarithm of international trade (exports plus imports) as a share of GDP, and (v) indicators of civil liberties, revolutions and coups, political assassinations, bureaucratic efficiency, and corruption. An assortment of research papers stresses the importance of macroeconomic policies and political factors in the process of economic growth. I control for these factors in order to assess the independent link between growth and both financial structure and overall financial development (Levine and Renelt, 1992). ${ }^{9}$

\section{Results}

\section{A. Financial Structure}

Table IV presents the financial structure results using ordinary least squares estimation with heteroskedasticity-consistent standard errors. The top panel lists the results for the simple conditioning information set for each of the five financial structure variables. The bottom panel lists the results for the full conditioning information set. I use a common sample throughout, so that there are 48 observations in all of the regressions (except as noted below). To concisely summarize a large number of regressions, I only report the results on the variable of interest: the financial structure variables.

Financial structure is not significantly related to economic growth. None of the financial structure indicators enters any of the growth regressions significantly at the 0.10 level. The results are inconsistent with both the bank-based and the market-based views. The bank-based view predicts a negative relationship between growth and the financial structure measures. The market-based view predicts a positive relationship. Rather, the results are more consistent with the financial services and law and finance views: they predict that financial structure is not the most useful way to distinguish financial systems. ${ }^{10}$ Furthermore, I modified the econometric specification to include both financial structure and 
overall financial development. The financial structure variables never enter the growth regression significantly. However, overall financial development is robustly linked with economic growth as discussed below. ${ }^{11}$

Finally, I assess the broad views of financial structure and economic growth that involve a bit more nuance. That is, Table V presents the results of estimating equations (4) and (5), in order to mitigate potential interpretational complexities and evaluate the predictions of an important set of models. As noted, Boyd and Smith (1998) argue that the optimal degree level of financial structure changes with income per capita. Rajan and Zingales (1998) instead argue that in countries with weak shareholder protection codes and poorly enforced property rights, bank-based systems will better promote growth, while economies benefit from more market-based systems as the legal system improves.

The results do not suggest that distinguishing countries as bank-based or market-based is an analytically useful way of distinguishing financial systems, even after allowing for the systematic evolution of financial structure (Table V). The first set of regressions (structure and income per capita) include the interaction term, $\mathrm{S}^{*} \mathrm{Y}$, where $\mathrm{S}$ is the financial structure indicator and $\mathrm{Y}$ is real per capita GDP. As shown, neither the structure variable nor the interactive term enters significantly. The second set of regressions (structure and shareholder rights) includes the index of the legal rights of (equity) shareholders independently and interacted with financial structure (S). ${ }^{12}$ This does not change the conclusions. None of the variables associated with financial structure enters significantly. The third set of regressions (structure and the rule of law) includes an index of the degree to which the country follows the rule of law, LAW. ${ }^{13}$ This is included independently and interacted with financial structure. Again, there is no evidence that financial structure is a useful way to distinguish financial systems in assessing long-run growth. Finally, I simply split the sample according to the level of economic development and analyzed OECD and non-OECD countries. Financial structure does not enter significantly in any of these regressions either. These results do not reject the theories outlined by Boyd and Smith (1998) and Rajan and Zingales (1998). These findings do, however, suggest that the absence of a link between growth and 
the level of bank-basedness or market-basedness is not due to countries selecting the optimal level of financial structure.

\section{B. Sensitivity of the Financial Structure Results}

While many of the robustness tests are detailed above, I explain a few additional ones here.

First, I use instrumental variables to control for potential simultaneity. I use three instrumental variables that explain cross-country differences in financial structure. All three variables come from LLSV (1998). The index of shareholder rights (defined above) does a particularly good job of explaining cross-country differences in stock market development. In turn, the LLSV index of creditor rights helps account for cross-country differences in banking sector development. ${ }^{14}$ The creditor rights index, however, does not explain much of the cross-country variation in stock market development. Since contract enforcement is important for both bank and market activities, I also include a measure of the law and order tradition of the country, LAW. Use of these instruments does not alter the results: financial structure is neither positively nor negatively related to economic growth. Alternative instruments tell the same story. I use legal origin to extract the exogenous component of financial structure. LLSV (1998) show the Common Law countries tend to have stronger investor protection laws and enforcement capabilities than French Civil Law countries. Using these alternative instruments, however, does not alter the results. $^{15}$

Second, the results in this paper have been checked using an alternative statistical procedure that (i) exploits the time-series (as well as the cross-country) dimension of the data, (ii) controls for the possibility that there is an important country-specific variable inducing omitted variable bias, and (iii) accounts for the possibility that financial structure and economic growth are simultaneously determined variables. Specifically, instead of conducting the analyses using a pure cross-country estimator with one observation per country, I use pooled cross-section, time-series procedures. The panel estimates, however, produce exactly the same results: while overall financial development is an important determinant of growth, financial structure is not systematically linked with economic performance. ${ }^{16}$ 
Finally, microeconomic evidence from individual country studies supports this paper's findings. For instance, Gallego and Loayza (2001) investigate the development of Chile's financial system over the last two decades using firm-level data and panel econometric techniques. They find that changes in financial structure did not influence the cost of capital in Chile or firms' access to capital. However, they do find that overall financial development lowered the cost of capital and eased financing constraints. Furthermore, using firm-level data from a cross-section of 33 countries, Beck, Demirguc-Kunt, Levine and Maksimovic (2001) find that overall financial development boosts firm growth, but financial structure is unrelated to firm performance. Finally, using industry level data across 42 countries, Beck and Levine (2002) find that while overall financial development boosts industry growth and new firm formation, having a bank-based or market-based financial system does not matter much.

\section{Financial Development}

The results are quite different when examining overall financial development. Past work has demonstrated a strong link between financial development and growth. Here, I show that the measures of overall financial development used in this paper are strongly linked with long-run growth and this relationship is not due to simultaneity bias.

Financial development - as measured by the conglomerate indices of bank activity and stock market activity -- is positively and significantly related to economic growth in the international crosssection of countries (Table VI) ${ }^{17}$ Indeed, the only financial development indicator that is not significantly related to growth is FINANCE-SIZE, which measures financial size. This result is consistent with the Levine and Zervos (1998) result that market capitalization is not a robust predictor of economic growth. They show that stock market liquidity, as measured by the total value traded ratio, and banking sector activity, as measured by bank credit to the private sector are robust predictors of growth. Thus, the Table VI results are consistent with the financial services and law and finance views. While they are also consistent with both the market-based and bank-based views of financial development, these views of financial structure did not fair very well in the specific examination of financial structure. 
Moreover, all of the overall financial development indicators continue to enter significantly in the simple growth regressions when controlling for financial structure.

These findings are consistent with the financial services view of financial structure and the coefficients suggest an economically large relationship between finance and growth. To illustrate the economic size of the coefficients in Table VI consider FINANCE-ACTIVITY, the overall financial activity measure, and its estimated coefficient of 0.435 in the full conditioning information set regression. Now consider changing Peru and Argentina's levels of overall financial activity from -6.6 and -6.0 respectively to the level of their neighbor Chile, which has a value of FINANCE-ACTIVITY of -4.0 over the 1980-95 period. The estimates suggest an increase in real per capital GDP growth of 1.15 percentage points for Peru and 0.89 percentage points in Argentina. This increase in growth is large. Over this period, Peru shrank at a rate of -1.8 percent per year while Argentina stagnated with an annual growth rate of 0.04 percent. Chile, however, might also strive for greater financial development. For instance, Thailand, which has similar real per capita GDP, has an overall financial sector activity index of -2.0, compared to Chile's value of -4.0 for FINANCE-ACTIVITY. If Chile had enjoyed Thailand's level of financial activity during this 15 -year period, the coefficient estimates suggest that Chile would have grown 0.86 percentage points faster each year (Chile's real per capita annual growth over the period averaged 3.7 percent). These examples are meant to illustrate the economic size of the coefficients and should not be viewed as exploitable elasticities. Nonetheless, the results indicate that the economic relationship between overall financial sector development and long-run growth is economically relevant.

\section{The Law and finance View}

Table I5 provides information on a special case of the financial services view: the law and finance view of financial structure. Here I use instrumental variables to extract that part of overall financial development determined by the legal environment. Specifically, I identify that component of financial development determined by (i) legal codes that support shareholders, (ii) legal codes that support creditors, and (iii) the efficiency with which law are enforced. I then assess whether this component of overall financial development is strongly linked with long-run growth. 
It is worth pointing out the desirability of using these legal indicators. Using a variety of econometric methods, earlier studies show that the exogenous component of financial development is positively linked with growth. ${ }^{18}$ Thus, while economic activity may influence financial development, the strong, positive link between financial development and growth is not fully explained by reverse causality: there is an exogenous component of financial development that positively influences growth. While these earlier studies were primarily interested in confronting the issue of exogeneity, the current study is primarily interested in assessing the law and finance view: Is that part of overall financial development defined by legal codes and enforcement capabilities helpful in explaining cross-country growth differences? Thus, we use measures of the rights of investors and the efficiency of contract enforcement. This may raise concerns that growth alters laws and enforcement. This is not a dominant influence, however. Levine (1999) uses the legal origin of each country as an instrumental variable in extracting the exogenous component of financial development. LLSV (1998) argue that legal origins French, English, German, or Scandinavian legal origin - were determined centuries earlier and were largely disseminated through conquest and colonization, so they can be treated as reasonably exogenous for current analyses. These legal origin variables explain differences in legal codes and enforcement efficiency. Critically, this paper's conclusions hold even when using legal origin as instrumental variables. Thus, I focus on using legal codes and law enforcement to extract this component of overall financial development, rather than replicating past work.

The results are consistent with the law and finance view: greater financial development, as defined by the legal environment, is positively related to economic growth (Table VII). Furthermore, the regressions pass the test of the overidentifying restrictions. That is, the data do not reject the hypothesis that shareholder rights, creditor rights, and the law and order tradition of the country influence growth only through their effects on financial development. Thus, the data are consistent with the view that the component of overall financial development explained by legal codes and enforcement efficiency is positively and significantly related to economic growth. Also, the instruments explain a significant amount of the cross-sectional variation in financial development in the first-stage regressions. ${ }^{19}$ Finally, 
the coefficient sizes do not shrink from the OLS regressions presented in Table VI. The economic impact of the exogenous component of financial sector development is economically large.

\section{Discussion}

The results provide strong support for the financial services view: overall financial development is strongly associated with growth. This close relationship holds after controlling for potential simultaneity bias, omitted variable bias, and wide range of sensitivity checks. Furthermore, while overall financial development is closely associated with economic growth, the degree to which financial structure is bank-based or market-based is not associated with growth. These findings are consistent with the financial services view.

Furthermore, the data support a special case of the financial services view of financial structure: the law and finance view. While the results on the law and finance view must be viewed cautiously, some additional information supports the law and finance view. In terms of caution, to derive conclusions about the law and finance view of financial structure from Table VII, one must interpret the results as supporting the contention that the component of financial development determined by specific legal variables is positively and significantly linked with growth. Although this is consistent with the results, this interpretation is inherently a structural statement. Nonetheless, it is important to highlight three pieces of information. First, as noted above, the three legal system variables jointly explain cross-country variation in the overall financial development indicators. Thus, the results accord with LLSV (1998) view that legal system differences account for differences in financial development. Second, the three legal system variables jointly explain economic growth. Specifically, when the three legal system variables are entered jointly in the full conditioning information set growth regression -- while excluding the financial development measures, an F-test on the three legal variables shows that they explain a significant proportion of the cross-country variation in economic growth. ${ }^{20}$ Third, I enter the three legal system variables in the growth regression along with the financial development indicator. The legal

variables do not enter significantly when controlling for overall financial development. ${ }^{21}$ This suggests 
that it is the ability of the legal variables to explain cross-country differences in financial development that is crucial for growth. This is exactly the law and finance view of financial structure.

\section{Conclusions}

This paper explores the relationship between economic performance and financial structure - the degree to which a country's financial system is market-based or bank-based. In particular, this paper empirically assesses competing theoretical views of financial structure and economic growth. The bankbased view holds that bank-based systems - particularly at early stages of economic development and in weak institutional settings - do a better job than market-based financial system at mobilizing savings, allocating capital and exerting corporate control. In contrast, the market-based view emphasizes that markets provide key financial services that stimulate innovation and long-run growth. Alternatively, the financial services view stresses the role of bank and markets in researching firms, exerting corporate control, creating risk management devices, and mobilizing society's savings for the most productive endeavors. This view minimizes the bank-based versus market-based debate and emphasizes the quality of financial services produced by the entire financial system. The law and finance view, which is a special case of the financial services view, argues that the legal system is the primary determinant of financial development. Thus, the law and finance view stresses the role of the legal system in boosting overall financial sector development and hence long-run growth.

The data provide no evidence for the bank-based or market based views. Distinguishing countries by financial structure does not help in explaining cross-country differences in long-run economic performance. Rather, the cross-country data strongly support the financial services view. Distinguishing countries by their overall level of financial development helps to explain cross-country difference in economic growth. Countries with greater degrees of financial development - as measured by aggregate measures of bank development and market development - enjoy substantially greater economic growth rates. Moreover, the component of financial development explained by the legal rights of outside investors and the efficiency of the legal system in enforcing those rights is strongly and 
positively linked with long-run growth. The data are consistent with the view that the legal system importantly influences financial sector development and this in turn influences long-run growth. 


\section{REFERENCE}

ALLEN, F. AND GALE, D. “Comparing Financial Systems,” MIT Press, Cambridge, MA.

ALLEN, F. AND GALE, D. (1999). Diversity of opinion and financing of new technologies, $J$. of Financial Intermediation 8, 1-22.

BANKS, A.S. (1994). "Cross-National time series data archive," Center for Social Analysis, State University of New York at Binghamton.

BARRO, R.J. AND LEE, J. (1996). International measures of schooling years and schooling quality, A.E.R. Papers and Proceedings 86, 218-223.

BARTH, J.R., CAPRIO, G., AND LEVINE, R. (2001a). Banking systems around the world: Do regulation and ownership affect performance and stability? in "Prudential Supervision: What Works and What Doesn't," (F. Mishkin, Ed.), pp. 31-88. NBER Press, Cambridge, MA:

BARTH, J.R., CAPRIO, G., AND LEVINE, R. (2001b). The regulation and supervision of banks around the world: A new database, in "Integrating Emerging Market Countries into the Global Financial System” (R. E. Litan and R. Herring, Eds.), pp. 183-240. Brookings Institution Press, Washington, D.C.

BARTH, J.R., CAPRIO, G., AND LEVINE, R (2001c). Bank regulation and supervision: What works best? University of Minnesota (Carlson School of Management), mimeo.

BECK, T., DEMIRGUC-KUNT, A., AND LEVINE, R. (2001). The financial structure database, in "Financial Structure and Economic Growth: A Cross-Country Comparison of Banks, Markets, and Development"(A. Demirguc-Kunt and R. Levine, Eds.), pp. 17-80. MIT Press, Cambridge, MA.

BECK, T., DEMIRGUC-KUNT, A., LEVINE, R., AND MAKSIMOVIC, V. (2001). Financial structure and economic development: Firm, industry, and country evidence, in "Financial Structure and Economic Growth: A Cross-Country Comparison of Banks, Markets, and Development"(A. Demirguc-Kunt and R. Levine, Eds.), pp. 189-242. MIT Press, Cambridge, MA.

BECK, T. AND LEVINE, R. (2002). Industry growth and capital allocation: Does having a market- or bank-based system matter? Journal of Financial Economics, forthcoming.

BECK, THORSTEN; LEVINE, ROSS; LOAYZA, NORMAN, (2000). Finance and the sources of growth, Journal of Financial Economics 58, 261-300.

BENCIVENGA, V.R. AND SMITH, B.D. (1991). Financial intermediation and endogenous growth, Review of Economics Studies 58, 195-209.

BENCIVENGA, VALERIE R.; SMITH, BRUCE D., and STARR, ROSS M. (1995) "Transactions costs, technological choice, and endogenous growth," Journal of Economic Theory 67, 53-177.

BHATTACHARYA, S.; BOOT, A.W.A.; A.V. THAKOR. (1998), The economics of bank regulation, Journal of Money, Credit, and Banking 30, 745-770.

BHATTACHARAY, S. AND CHIESA, G. (1995). Financial intermediation with proprietary information, J. of Financial Intermediation 4, 328-57.

BHIDE, AMAR (1993). The hidden costs of stock market liquidity, Journal of Financial Intermediation 34, 1-51.

BLACK, STANLEY W. and MOERSCH, MATHIAS. (1998) Financial structure, investment and economic growth in OECD countries in "Competition and Convergence in Financial Markets: The German and Anglo-American Models" (Stanley W. Black and Mathias Moersch, Eds), pp. 157-174. New York: North-Holland Press.

BOOT, A.W. AND THAKOR, A.V. (1997). Financial system architecture, Rev. of Financial Studies 10, 693-733.

BOOT, A.W. AND THAKOR, A.V. (2000). Can relationship banking survive competition?, J. of Finance 55, 679-713.

BOOT, A.W., GREENBAUM, S.I., AND THAKOR, A.V. (1993). Reputation and discretion in financial contracting, American Economic Review 83, 1165-83. 
BOYD, JOHN H. AND SMITH, BRUCE D. (1998). The evolution of debt and equity markets in economic development, Economic Theory 12, 519-60.

BUSINESS INTERNATIONAL CORPORATION (1984), Introduction to the country assessment service business, International Corporation, New York, NY.

DEMIRGUC-KUNT, ASLI and LEVINE, ROSS. (2001). Bank-based and market-based financial systems: Cross-country comparisons. in "Financial Structure and Economic Growth: A CrossCountry Comparison of Banks, Markets, and Development", (Asli Demirguc-Kunt and Ross Levine, Eds.), pp. 81-140. MIT Press, Cambridge, MA

DEWATRIPONT, M. AND MASKIN, E. (1995). Credit and efficiency in centralized versus decentralized markets, Rev. of Economics Studies 62, 541-555.

DIAMOND, D. (1984). Financial intermediation and delegated monitoring, Rev. of Econ. Studies 51, 393-414.

EASTERLY, WILLIAM AND LEVINE, ROSS (1997). Africa's growth tragedy: Policies and ethnic divisions, Quarterly Journal of Economics 112, 1203-1250.

EASTERLY, WILLIAM AND LEVINE, ROSS (2001). Factor accumulation is not the answer: Stylized facts and growth models, World Bank Economic Review.

GALLEGO, FRANCISCO AND LOAYZA, NORMAN. (2001). Financial structure in Chile, in "Financial Structure and Economic Growth: A Cross-Country Comparison of Banks, Markets, and Development" (A. Demirguc-Kunt and R. Levine, Eds.), pp. 299-346, MIT Press, Cambridge, MA.

GERSCHENKRON, ALEXANDER (1962). "Economic Backwardness in Historical Perspective, A Book of Essays." Harvard University Press, Cambridge, MA.

GOLDSMITH, RAYMOND, W. (1969) "Financial Structure and Development." Yale University Press, New Haven, CT.

HOMSTROM, B. AND TIROLE, J. (1993). Market liquidity and performance monitoring, J. of Political Economy 101, 678-709

HOSHI, TAKEO, KASHYAP, ANIL, SCHARFSTEIN, DAVID (1991). Corporate structure, liquidity, and investment: Evidence from Japanese industrial groups, Quarterly Journal of Economics 106, 33-60.

JENSEN, M.C. AND MURPHY, K.J. (1990). Performance pay and top-management incentives, J. of Political Economy 98, 225-64.

KING, ROBERT G. AND LEVINE, ROSS (1993a). Finance and growth: Schumpeter might be right, Quarterly Journal of Economics 108, 717-38.

KING, ROBERT G. AND LEVINE, ROSS (1993b). Finance, entrepreneurship, and growth: Theory and evidence, Journal of Monetary Economics 32, 513-42.

LAPORTA, RAFAEL; LOPEZ-DE-SILANES, FLORENCIO; SHLEIFER, ANDREI; AND VISHNY, ROBERT W. (2000). Investor protection and corporate governance, Journal of Financial Economics 58, 3-27.

LAPORTA, RAFAEL; LOPEZ-DE-SILANES, FLORENCIO; SHLEIFER, ANDREI; AND VISHNY, ROBERT W. (1999). The quality of government, Journal of Law, Economics, and Organization 15, 222-279.

LAPORTA, RAFAEL; LOPEZ-DE-SILANES, FLORENCIO; SHLEIFER, ANDREI; AND VISHNY, ROBERT W. (1998). Law and finance, Journal of Political Economy 106, 1113-1155

LEVINE, R. (1991). Stock markets, growth, and tax policy, J.Finance 46, 1445-65.

LEVINE, ROSS (1997). Financial development and economic growth: Views and agenda, Journal of Economic Literature 35, 688-726.

LEVINE, ROSS (1999a). Law, finance, and economic growth, Journal of Financial Intermediation $\mathbf{8}$, 36-67.

LEVINE, ROSS; LOAYZA, NORMAN; BECK, THORSTEN (2000). Financial intermediation and growth: Causality and causes, Journal of Monetary Economics 46, 31-77.

LEVINE, ROSS AND RENELT, DAVID (1992). A sensitivity analysis of cross-country growth 
regressions, American Economic Review 82, 942-63.

LEVINE, ROSS AND ZERVOS, SARA (1998). Stock markets, banks, and economic growth,_American Economic Review 88, 537-558.

MERTON, ROBERT C. AND BODIE, ZVI (1995). A conceptual framework for analyzing the financial environment, in "The Global Financial System: A Functional Perspective" (Dwight B. Crane et al., Eds.), pp. 3-32. Harvard Business School Press, Boston, MA.

MORK, RANDALL AND NAKKAMURA, MASAO (1999). Banks and corporate control in Japan, Journal of Finance 54, 319-40.

OBSTFELD, M. (1994). Risk-taking, global diversification, and growth, American Economic Review 84, 1310-29

PICK'S CURRENCY YEARBOOK, various years, Pick Publishing Corporation, New York, NY.

POLITICAL RISK SERVICES, Various years, International Country Risk Guide, Syracuse, NY.

RAJAN, RAGHURAM G. (1992). Insiders and outsiders: The choice between informed and arms length debt, Journal of Finance 47, 1367-1400.

RAJAN, RAGHURAM G. AND ZINGALES, LUIGI (1998). Which capitalism? Lessons from the East Asian crisis, Journal of Applied Corporate Finance 11, 40-48.

RAMAKRISHNAN, R.T.S. AND THAKOR, A.V. (1984). Information reliability and a theory of financial intermediation, Rev. of Financial Studies 51, 415-432.

SIRRI, E.R. AND TUFANO, P. (1995). The economics of pooling, in "The Global Financial System: A Functional Approach" (D.B. Crane, et al., Eds.), pp. 81-128. Harvard Business School Press, Cambridge, MA.

STIGLITZ, JOSEPH E. (1985). Credit markets and the control of capital, Journal of Money, Credit and Banking, 17, 133-52.

VON THADDEN, E.L. (1995). Long-term contracts, short-term investment and monitoring, Rev. of Economic Studies 62, 557-575.

WEINSTEIN, DAVID E. AND YAFEH, YISHAY (1998). On the costs of a bank-centered financial system: Evidence from the changing main bank relations in Japan, Journal of Finance 53, 635672.

WENGER, EKKEHARD AND KASERER, CHRISTOPH (1998). The German system of corporate governance: A model which should not be imitated, in "Competition and Convergence in Financial Markets: The German and Anglo-American Models" (Stanley W. Black and Mathias Moersch, Eds), pp. 41-78. North -Holland Press, New York.

WURGLER, JEFFREY (2000). Financial markets and the allocation of capital, Journal of Financial Economics 58, 187-214.

WORLD CURRENCY YEARBOOK, various issues, International Currency Analysis Inc, New York, NY. 

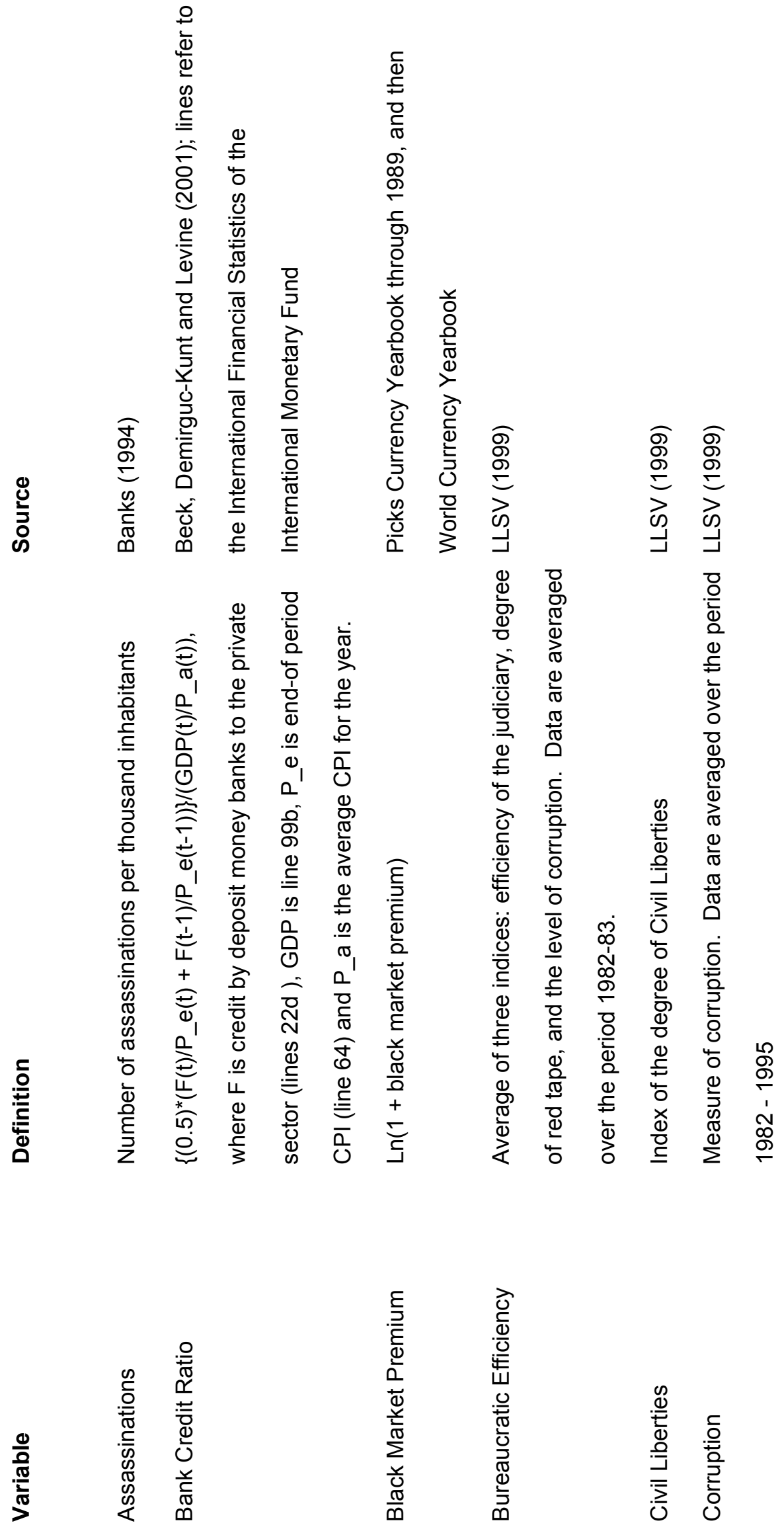


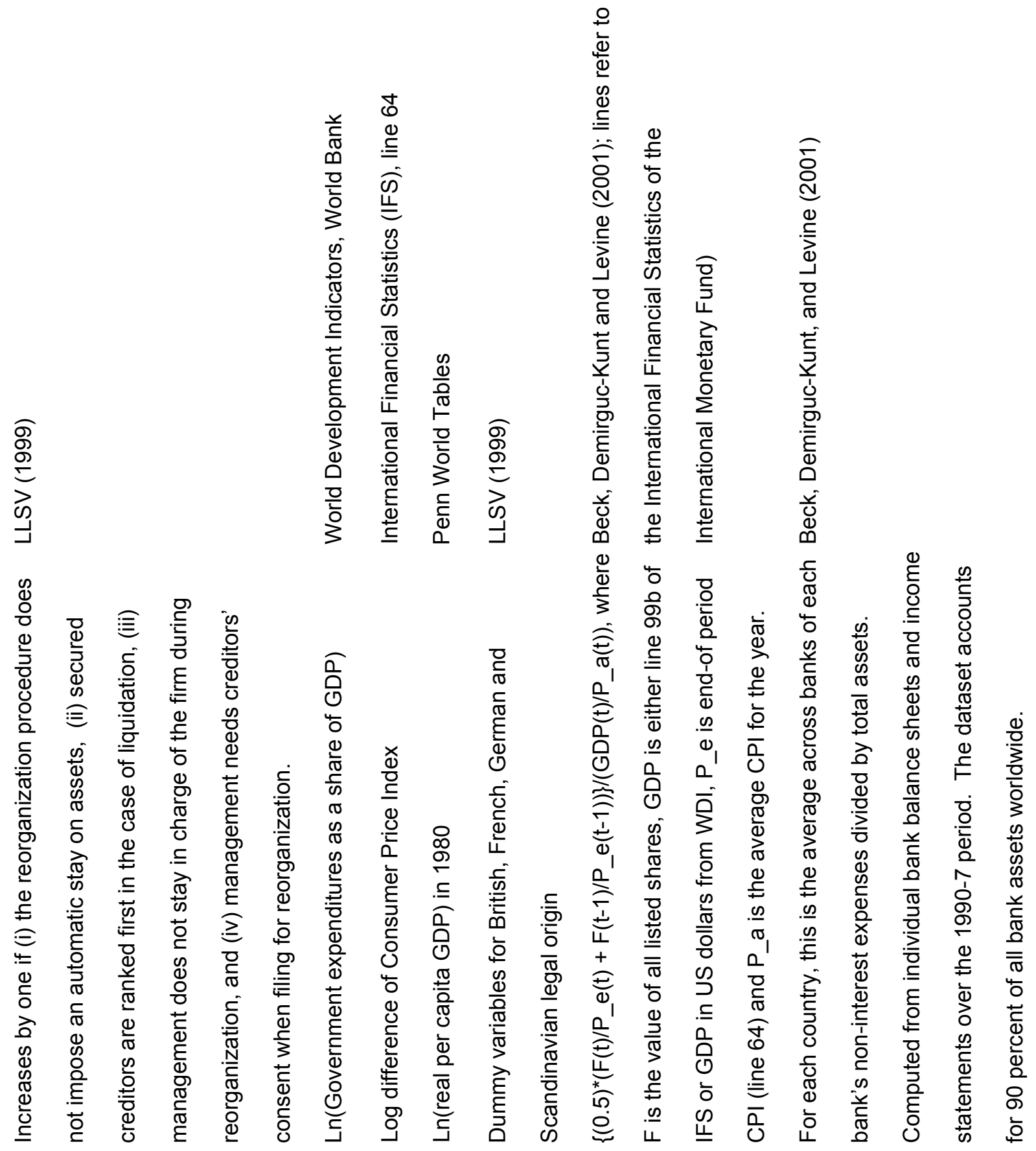

总

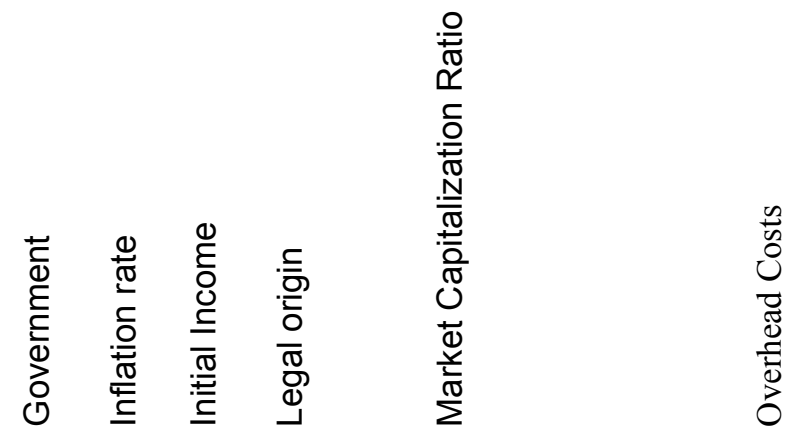



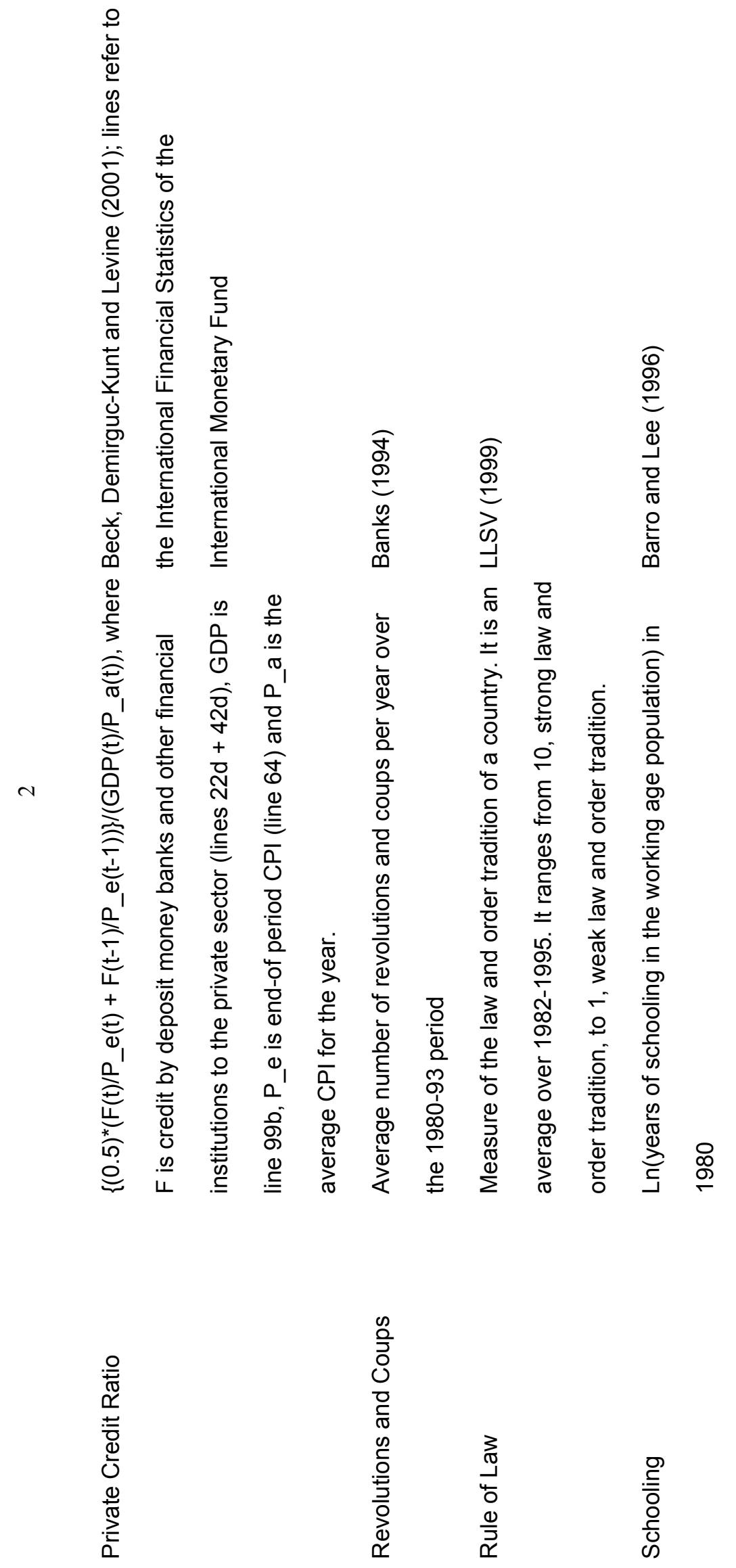
क
ब
क
J

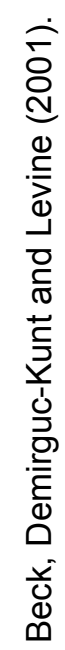

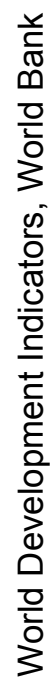

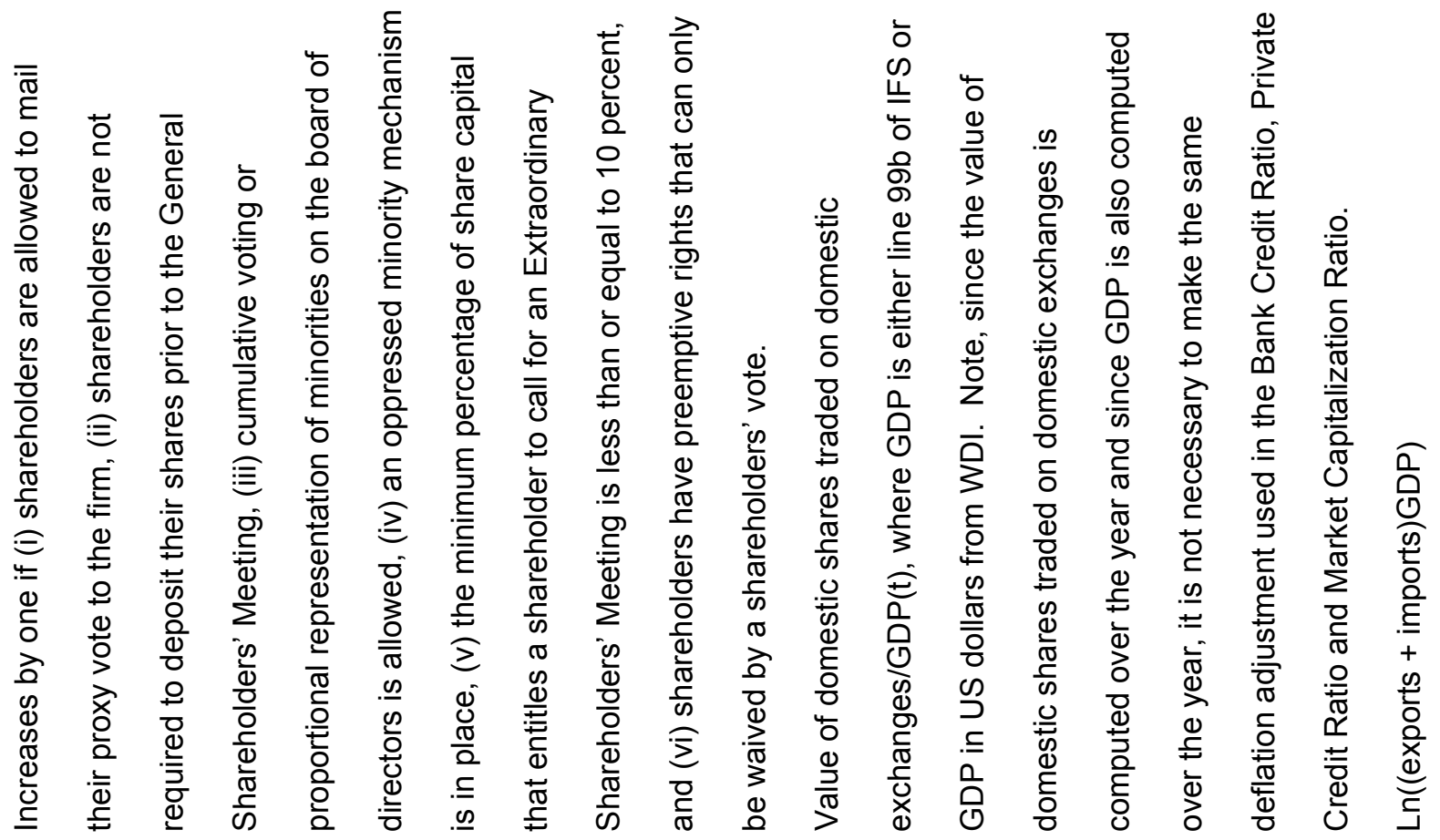

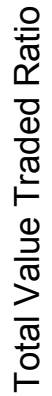

$\stackrel{\frac{0}{0}}{\stackrel{\pi}{2}}$ 


\section{Footnotes}

${ }^{1}$ Allen and Gale (1999) comprehensively review the vast literature on comparative financial systems.

${ }^{2}$ See Goldsmith (1969), Hoshi, Kashyap, and Scharfstein (1991), Levine (1997), Mork and Nakkamura (1999), Weinstein and Yafeh (1998) and Wenger and Kaserer (1998).

${ }^{3}$ Bhattacharya and Chiesa (1995), Dewatripont and Maskin (1995), and von Thadden (1995) examine the allocative efficiency of bank-based and market-based systems. Boot and Thakor (2000) explore the impact of markets on banks. For additional citations and discussion on the role of financial systems in economic growth, see Levine (1997).

${ }^{4}$ Black and Moersch (1998a) start down this path by examining OECD countries.

${ }^{5}$ Goldsmith (1969) made this argument when discussing Germany's bank-based system and the United Kingdom's market-based system during the period 1864-1914: "One cannot well claim that a superiority in the German financial structure was responsible for, or even contributed to, a more rapid growth of the German economy as a whole compared to the British economy in the halfcentury before World War I, since there was not significant difference in the rate of growth of the two economies." (p. 407)

${ }^{6}$ Barth, Caprio, and Levine (2001a) examine the links between bank performance and regulatory powers. Barth, Caprio, and Levine $(2001 \mathrm{~b}, \mathrm{c})$ present a new data set of bank regulation and supervision and then use these data to examine the relationship between the regulatory and supervisory regime and both bank performance and stability. For a helpful review of the economics of bank regulation, see Bhattacharya, Boot, and Thakor (1998).

${ }^{7}$ The countries with below median values of bank credit, market capitalization, total value traded and above median values of overhead costs are Argentina, Colombia, Ecuador, Ghana, Greece, Honduras, Kenya, Peru, Sri Lanka, Trinidad and Tobago, and Zimbabwe. 
${ }^{8}$ Furthermore, I examined "unbalanced financial systems." Countries with well-developed banks and poorly developed markets, or vice-versa, may have distorted financial structures that hinder the efficient provision of financial services. However, identifying countries with very unbalanced financial systems does not help explain growth.

${ }^{9}$ Recent work stresses that religious composition and geographical endowments (such as distance from the equator) influence financial development. When controlling for these factors, the results on financial structure reported below are unaltered.

${ }^{10}$ I tested robustness using an array of different indicators of financial structure. Specifically, instead of using total value traded of equity shares relative to GDP to measure stock markets development, I used total value traded relative to market capitalization. The results are the same. Then, instead of using secondary market measures of stock market development, I used primary market measures. Thus, I computed the amount of money obtained by the issuance of equity and used this as the indicator of stock market development. Again, the results are the same. Also, I used expanded measures of banking development that include measures of privately owned life insurance companies and private pension funds. The conclusions are the same. Also, controlling for the extent of public ownership of banks does not change the findings. Finally, I used the structureaggregate indicator to compute a zero-one structure-dummy variable of whether each country's financial system is bank-based or market-based and get the same results.

${ }^{11}$ I assessed the empirical link between financial structure and the individual sources of growth: total factor productivity growth, physical capital accumulation, and private saving rates using data from Easterly and Levine (2001). Some models, for instance, suggest that bank-based systems are particularly important for capital-based growth, while market-based system are crucial for innovation led growth (Allen and Gale, 1999). There is not a significant link - positive or negative 
- between financial structure and any of the sources of economic growth. Also, Wurgler (2000) measures efficient capital allocation as the degree to which investment flows into industries with growing value added and out of industries with declining value added. I found that the degree to which an economy has a bank-based or market-based system is unrelated to Wurlger's (2000) measure of efficient capital allocation.

${ }^{12}$ Specifically, for shareholder rights, I add 1 if: (1) the country allows the shareholders to mail their proxy to the firm; (2) shareholders are not required to deposit their shares prior to the General Shareholders' Meeting; (3) cumulative voting or proportional representation of minorities in the board of directors is allowed; (4) an oppressed minorities mechanism is in place; (5) the minimum percentage of share capital that entitles a shareholder to call for an Extraordinary Shareholders' Meeting is less than or equal to 10 percent (the sample median); or (6) shareholders have preemptive rights that can only be waived by a shareholders' vote.

${ }^{13} \mathrm{LAW}$ ranges from 10 (strong law and order tradition) to 1 (weak law and order tradition). The data are averaged over the period 1982-95. LAW is very highly correlated with indexes of the security of property rights and the efficiency of contract enforcement. Using these alternative measures of legal development does not alter the conclusions.

${ }^{14}$ Specifically, for creditor rights I add one if (1) the country imposes restrictions, such as creditors' consent, to file for reorganization; (2) secured creditors are able to gain possession of their security once the reorganization petition has been approved (no automatic stay); (3) secured creditors are ranked first in the distribution of the proceeds that result from the disposition of assets of a bankrupt firm; and (4) the debtor does not retain the administration of its property pending the resolution of the reorganization. 
${ }^{15}$ Furthermore, I assess whether financial structure measured in 1980 explains subsequent growth. It does not.

${ }^{16} \mathrm{I}$ have also examined the links between financial structure and both output volatility and banking sector crises. Financial structure is not related to the probability of suffering a major banking crisis, or to output growth volatility. Thus, distinguishing between bank-based and market-based financial systems is not particularly useful for understanding long-run growth, output volatility, or financial fragility.

${ }^{17}$ I also confirm earlier findings by King and Levine (1993a,b), Levine and Zervos (1998), and Beck, Levine, and Loayza (2000) using this paper's new overall financial development indicators: financial development is closely linked with total factor productivity growth but not robustly linked with capital accumulation or private saving rates.

${ }^{18}$ See Levine (1999) and Levine, Loayza, and Beck (2000).

${ }^{19}$ For instance, the instruments are jointly significant in the FINANCE-ACTIVITY first-stage regression at the 0.01 level and account for 50 percent of its cross-country variance. ${ }^{20}$ Specifically, the F-statistic equals 3.01 with a P-value of 0.048 .

${ }^{21}$ Specifically, the P-values on the F- statistic (when testing the joint significance of the legal variables while controlling for overall financial development) are typically greater than 0.45 . 
Ranked Structure Indices

\begin{tabular}{|c|c|c|c|c|c|c|c|c|c|}
\hline $\begin{array}{l}\text { STRUCTURE } \\
\text { ACTIVITY }\end{array}$ & & $\begin{array}{l}\text { STRUCTURE } \\
\text { SIZE }\end{array}$ & & $\begin{array}{l}\text { STRUCTURE } \\
\text { EFFICIENCY }\end{array}$ & & $\begin{array}{l}\text { STRUCTURE } \\
\text { AGGREGATE }\end{array}$ & & $\begin{array}{l}\text { STRUCTURE } \\
\text { REGULATORY }\end{array}$ & \\
\hline Taiwan & 0.59 & Ghana & 1.34 & Switzerland & -3.03 & Taiwan & 1.86 & New Zealand & 4 \\
\hline Malaysia & -0.32 & South Africa & 0.94 & Taiwan & -3.62 & Malaysia & 1.59 & Austria & 5 \\
\hline Switzerland & -0.39 & Malaysia & 0.60 & U.S.A. & -4.38 & Switzerland & 1.58 & Germany & 5 \\
\hline U.S.A. & -0.64 & Jamaica & 0.08 & U.K. & -4.79 & U.S.A. & 1.34 & Switzerland & 5 \\
\hline Ireland & -0.64 & Zimbabwe & 0.03 & Brazil & -4.87 & U.K. & 1.24 & United Kingdom & 5 \\
\hline Turkey & -0.73 & U.K. & 0.02 & Malaysia & -4.97 & Brazil & 1.01 & France & 6 \\
\hline U.K. & -0.74 & Mexico & -0.02 & Israel & -5.10 & Mexico & 0.90 & Netherlands & 6 \\
\hline Mexico & -0.85 & New Zealand & -0.02 & Japan & -5.24 & Japan & 0.86 & Argentina & 7 \\
\hline Brazil & -0.92 & Ireland & -0.03 & Germany & -5.26 & South Africa & 0.85 & Canada & 7 \\
\hline Thailand & -0.92 & Chile & -0.03 & Sweden & -5.47 & Canada & 0.82 & Finland & 7 \\
\hline Japan & -1.00 & Canada & -0.06 & Thailand & -5.52 & Sweden & 0.80 & Philippines & 7 \\
\hline Canada & -1.14 & Peru & -0.07 & Turkey & -5.54 & Australia & 0.80 & Spain & 7 \\
\hline Israel & -1.15 & ustralia & -0.09 & Australia & -5.58 & Israel & 0.75 & Sri Lanka & 7 \\
\hline Sweden & -1.18 & hilippines & -0.10 & Canada & -5.59 & Turkey & 0.71 & Australia & 8 \\
\hline Australia & -1.18 & U.S.A. & -0.11 & France & -5.60 & Thailand & 0.68 & Cyprus & 8 \\
\hline Netherlands & -1.36 & Sweden & -0.15 & Mexico & -5.75 & Philippines & 0.58 & Jenmark & 8 \\
\hline Philippines & -1.47 & Brazil & -0.31 & South Africa & -5.91 & New Zealand & 0.49 & reland & 8 \\
\hline Germany & -1.52 & Japan & -0.35 & Philippines & -5.92 & Peru & 0.39 & Norway & 8 \\
\hline Peru & -1.54 & elgium & -0.36 & Denmark & -6.08 & Jamaica & 0.38 & Panama & 8 \\
\hline India & 61 & Sri Lanka & -0.39 & New Zealand & -6.12 & Ireland & 0.33 & Peru & 8 \\
\hline New Zealand & -1.64 & Ecuador & -0.43 & Jamaica & -6.12 & Netherlands & 0.33 & South Africa & 8 \\
\hline Denmark & -1.87 & Kenya & -0.48 & Spain & -6.14 & Germany & 0.17 & Belgium & 9 \\
\hline Africa & -1.90 & Taiwan & -0.53 & Netherlands & -6.26 & Denmark & 0.17 & Greece & 9 \\
\hline Jamaica & -2.04 & Israel & -0.56 & Argentina & -6.28 & Ghana & 0.16 & Honduras & 9 \\
\hline Norway & -2.06 & Nether & -0.60 & Norway & -6.49 & India & 0.14 & Por & 9 \\
\hline rge & -2.15 & India & -0.60 & eru & -6.53 & Ch & 0.00 & en & 9 \\
\hline hat & -2.17 & enma & -0.62 & ly & -6.54 & Ecuador & -0.04 & Thailand & 9 \\
\hline Ecuador & -2.19 & Thailand & -0.66 & India & -6.58 & Belgium & -0.17 & Trin. \& Tob. & 9 \\
\hline France & -2.28 & Switzerland & -0.71 & Ecuador & -6.65 & France & -0.17 & Brazil & 10 \\
\hline Honduras & -2.34 & Turkey & -0.74 & Chile & -6.74 & Argentina & -0.18 & Colombia & 10 \\
\hline Spain & -2.36 & Colombia & -0.78 & Austria & -6.92 & Norway & -0.23 & India & 10 \\
\hline Belgium & -2.38 & Pakistan & -0.98 & Belgium & -6.94 & Spain & -0.31 & Italy & 10 \\
\hline Chile & -2.46 & Trin. \& Tob. & -1.00 & Honduras & -7.06 & Zimbabwe & -0.35 & Kenya & 10 \\
\hline Pakistan & -2.51 & Greec & -1.02 & Finland & -7.23 & Sri Lanka & -0.41 & Malaysia & 10 \\
\hline Italy & -2.52 & Argentina & -1.09 & yprus & -7.31 & Italy & -0.55 & Pakistan & 10 \\
\hline Zimb & -2.58 & Cyprus & -1.11 & Sri Lanka & -7.37 & Pakistan & -0.62 & Chile & 11 \\
\hline Greece & -2.65 & orway & -1.15 & Greece & -7.37 & Honduras & -0.63 & Ghana & 12 \\
\hline Sri Lanka & -2.66 & Finland & -1.29 & Pakistan & -7.47 & Greece & -0.66 & Jamaica & 12 \\
\hline Finland & -2.72 & Spain & -1.29 & Colombia & -7.50 & Colombia & -0.75 & Mexico & 12 \\
\hline Austria & -3.04 & France & -1.42 & Portugal & -7.52 & Finland & -0.76 & Taiwan & 12 \\
\hline & -3.0 & Italy & -1.45 & Trin. \& Tob. & -7.72 & Trin. \& Tob. & -1.04 & Turkey & 12 \\
\hline & -3.40 & Honduras & -1.46 & Zimbabwe & -7.88 & & -1.05 & United States & 12 \\
\hline Trin. \& Tob. & -3.41 & Germany & -1.53 & Ireland & -8.02 & Austria & -1.27 & Egypt & 13 \\
\hline Cyprus & -3.62 & Egypt & -1.54 & Ghana & -8.52 & Kenya & -1.37 & Israel & 13 \\
\hline Kenya & -3.93 & Tunisia & -1.91 & Kenya & -8.88 & Portugal & -1.43 & Japan & 13 \\
\hline Egypt & -4.14 & Panama & -1.94 & Tunisia & -8.90 & Egypt & -2.09 & Zimbabwe & 14 \\
\hline Tunisia & -4.29 & Portugal & -2.10 & Egypt & -9.60 & Tunisia & -2.09 & Ecuador & ND \\
\hline Panama & -5.17 & Austria & -2.46 & Panama & -9.98 & Panama & -2.75 & Tunisia & ND \\
\hline
\end{tabular}

Notes:

Structure-Activity $=$ Ln (total value traded ratio / bank credit ratio).

Structure-Size $=\mathrm{Ln}$ (market capitalization ratio / bank credit ratio).

Structure-Efficiency $=\operatorname{Ln}$ (total value traded ratio * overhead costs).

Structure-Aggregate $=$ principal component of Structure 1, 2, 3 .

Structure-Regulatory $=$ Index of regulatory restrictions on commercial bank activities. 
TABLE II

Financial Development

\begin{tabular}{|c|c|c|c|c|c|c|c|}
\hline $\begin{array}{l}\text { FINANCE } \\
\text { ACTIVITY }\end{array}$ & & $\begin{array}{l}\text { FINANCE } \\
\text { SIZE }\end{array}$ & & $\begin{array}{l}\text { FINANCE } \\
\text { EFFICIENCY }\end{array}$ & & $\begin{array}{l}\text { FINANCE } \\
\text { AGGREGATE }\end{array}$ & \\
\hline Switzerland & 0.55 & Switzerland & 5.51 & Taiwan & 4.43 & Switzerland & 1.88 \\
\hline Taiwan & 0.31 & Japan & 5.49 & Ireland & 4.14 & Taiwan & 1.84 \\
\hline Japan & -0.43 & South Africa & 5.35 & Japan & 3.32 & Japan & 1.76 \\
\hline U.S.A. & -0.80 & U.S.A. & 5.24 & Malaysia & 3.27 & Malaysia & 1.52 \\
\hline Malaysia & -1.08 & Malaysia & 5.23 & Switzerland & 2.98 & U.S.A. & 1.37 \\
\hline U.K. & -1.33 & Netherlands & 5.13 & Netherlands & 2.95 & Netherlands & 1.35 \\
\hline Netherlands & -1.41 & U.K. & 5.02 & U.K. & 2.72 & U.K. & 1.27 \\
\hline Germany & -1.76 & Sweden & 4.99 & Thailand & 2.33 & Ireland & 1.11 \\
\hline Sweden & -1.91 & Taiwan & 4.94 & U.S.A. & 2.24 & Sweden & 0.92 \\
\hline Thailand & -1.98 & Australia & 4.82 & Germany & 1.91 & Germany & 0.89 \\
\hline Canada & -2.14 & Canada & 4.81 & Canada & 1.84 & Thailand & 0.86 \\
\hline Australia & -2.14 & Germany & 4.71 & Australia & 1.71 & Canada & 0.86 \\
\hline Ireland & -2.41 & France & 4.71 & Sweden & 1.49 & Australia & 0.84 \\
\hline Israel & -2.52 & Norway & 4.64 & Israel & 1.43 & South Africa & 0.79 \\
\hline France & -2.57 & Cyprus & 4.57 & New Zealand & 1.07 & Israel & 0.51 \\
\hline South Africa & -2.81 & New Zealand & 4.55 & Finland & 0.98 & France & 0.50 \\
\hline Norway & -2.91 & Thailand & 4.55 & Norway & 0.91 & Norway & 0.47 \\
\hline Spain & -3.11 & Austria & 4.54 & South Africa & 0.75 & New Zealand & 0.42 \\
\hline New Zealand & -3.14 & Chile & 4.54 & France & 0.64 & Spain & 0.30 \\
\hline Austria & -3.36 & Spain & 4.50 & Denmark & 0.58 & Finland & 0.28 \\
\hline Finland & -3.52 & Ireland & 4.49 & Spain & 0.57 & Austria & 0.26 \\
\hline Denmark & -3.63 & Finland & 4.45 & India & 0.52 & Chile & 0.10 \\
\hline Italy & -3.89 & Israel & 4.37 & Austria & 0.48 & Denmark & 0.05 \\
\hline Chile & -3.96 & Portugal & 4.26 & Mexico & 0.23 & Italy & -0.09 \\
\hline Brazil & -4.14 & Tunisia & 4.16 & Chile & 0.20 & Belgium & -0.16 \\
\hline Philippines & -4.17 & Denmark & 4.16 & Belgium & 0.19 & Portugal & -0.17 \\
\hline Portugal & -4.32 & Belgium & 4.14 & Italy & 0.13 & Cyprus & -0.21 \\
\hline India & -4.35 & Italy & 4.13 & Philippines & 0.03 & Philippines & -0.26 \\
\hline Belgium & -4.37 & Trin. \& Tob. & 4.11 & Turkey & -0.03 & India & -0.30 \\
\hline Cyprus & -4.44 & Panama & 4.06 & Portugal & -0.19 & Mexico & -0.49 \\
\hline Mexico & -4.50 & Jamaica & 3.95 & Pakistan & -0.45 & Brazil & -0.53 \\
\hline Turkey & -4.77 & Philippines & 3.91 & Brazil & -0.62 & Jamaica & -0.55 \\
\hline Jamaica & -4.82 & Greece & 3.88 & Honduras & -0.76 & Tunisia & -0.58 \\
\hline Greece & -5.05 & Kenya & 3.71 & Greece & -0.92 & Greece & -0.62 \\
\hline Honduras & -5.15 & India & 3.69 & Jamaica & -0.96 & Trin. \& Tob. & -0.67 \\
\hline Trin. \& Tob. & -5.32 & Brazil & 3.60 & Tunisia & -1.00 & Honduras & -0.77 \\
\hline Pakistan & -5.41 & Zimbabwe & 3.56 & Cyprus & -1.06 & Pakistan & -0.78 \\
\hline Tunisia & -5.52 & Honduras & 3.52 & Sri Lanka & -1.26 & Turkey & -0.81 \\
\hline Ecuador & -5.75 & Colombia & 3.51 & Zimbabwe & -1.37 & Panama & -0.95 \\
\hline Sri Lanka & -5.97 & Egypt & 3.50 & Trin. \& Tob. & -1.52 & Sri Lanka & -1.03 \\
\hline Argentina & -5.99 & Mexico & 3.47 & Ecuador & -1.52 & Zimbabwe & -1.04 \\
\hline Zimbabwe & -6.14 & Pakistan & 3.47 & Egypt & -1.55 & Ecuador & -1.10 \\
\hline Colombia & -6.31 & Sri Lanka & 3.47 & Panama & -1.76 & Egypt & -1.23 \\
\hline Panama & -6.55 & Ecuador & 3.35 & Argentina & -1.91 & Kenya & -1.27 \\
\hline Peru & -6.60 & Turkey & 2.99 & Peru & -2.02 & Colombia & -1.31 \\
\hline Kenya & -6.83 & Argentina & 2.99 & Kenya & -2.30 & Argentina & -1.39 \\
\hline Egypt & -6.85 & Peru & 2.76 & Colombia & -2.51 & Peru & -1.62 \\
\hline Ghana & -9.07 & Ghana & 2.73 & Ghana & -2.71 & Ghana & -2.20 \\
\hline
\end{tabular}

Notes

Finance-Activity $=\operatorname{Ln}$ (total value traded ratio * private credit ratio).

Finance-Size $=$ Ln (market capitalization ratio + private credit ratio).

Finance-Efficiency $=$ Ln (total value traded ratio / overhead costs).

Finance-Aggregate $=$ Principal component of Finance 1, 2, 3. 


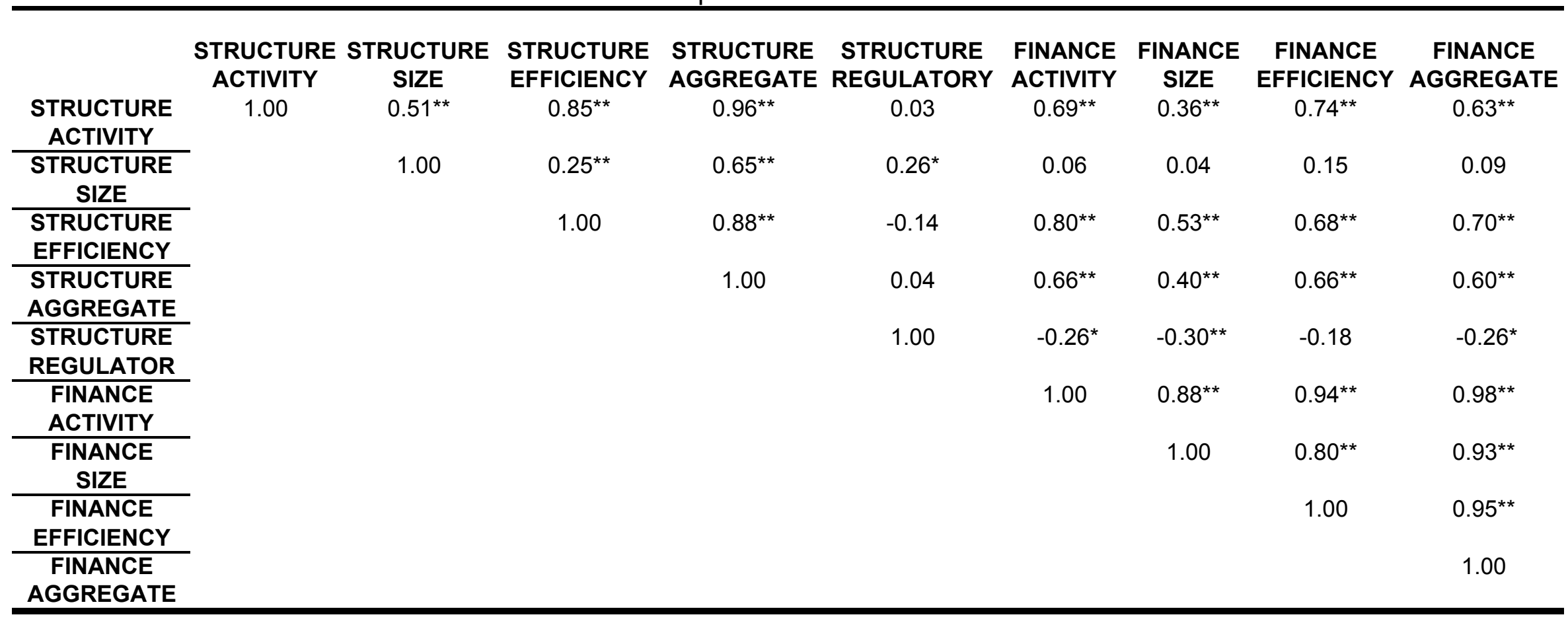

\section{Notes:}

${ }^{* *}$ indicates significant at the 0.01 level and * indicates signifcant at the 0.05 level

Structure-Activity $=\mathrm{Ln}$ (total value traded ratio / bank credit ratio).

Structure-Size $=\operatorname{Ln}$ (market capitalization ratio / bank credit ratio).

Structure-Efficiency $=$ Ln (total value traded ratio * overhead costs).

Structure-Aggregate $=$ principal component of Structure 1, 2, 3.

Structure-Regulatory $=$ Index of regulatory restrictions on commercial bank activities.

Finance-Activity $=\mathrm{Ln}$ (total value traded ratio * private credit ratio).

Finance-Size $=\operatorname{Ln}$ (market capitalization ratio + private credit ratio).

Finance-Efficiency $=\mathrm{Ln}$ (total value traded ratio $/$ overhead costs).

Finance-Aggregate $=$ Principal component of Finance 1, 2, 3. 


\section{TABLE IV}

Financial Structure and Economic Growth

Dependent variable: Real per Capita GDP Growth, 1980-95

\section{Simple Conditioning Information Set}

\begin{tabular}{l|ccc|c|c}
$\begin{array}{l}\text { Explanatory } \\
\text { Variable }\end{array}$ & $\begin{array}{c}\text { coefficient } \\
\text { standard } \\
\text { error }\end{array}$ & t-statistic & P-value & $\begin{array}{c}\text { R- } \\
\text { Squared }\end{array}$ \\
\hline Structure-Activity & 0.474 & 0.285 & 1.659 & 0.104 & 0.086 \\
Structure-Size & -0.318 & 0.350 & -0.909 & 0.368 & 0.019 \\
Structure-Efficiency & 0.373 & 0.255 & 1.460 & 0.151 & 0.069 \\
Structure-Aggregate & 0.365 & 0.313 & 1.167 & 0.250 & 0.039 \\
Structure-Regulatory & 0.118 & 0.107 & 1.099 & 0.278 & 0.024
\end{tabular}

\section{Full Conditioning Information Set}

\begin{tabular}{l|ccc|c|c}
$\begin{array}{l}\text { Explanatory } \\
\text { Variable }\end{array}$ & \multicolumn{5}{c}{$\begin{array}{c}\text { coefficient } \\
\text { standard } \\
\text { error }\end{array}$} \\
\hline Structure-Activity & 0.455 & 0.305 & 1.493 & 0.145 & 0.405 \\
Structure-Size & -0.605 & 0.517 & -1.170 & 0.250 & 0.386 \\
Structure-Efficiency & 0.336 & 0.259 & 1.299 & 0.203 & 0.392 \\
Structure-Aggregate & 0.315 & 0.321 & 0.982 & 0.333 & 0.372 \\
Structure-Regulatory & 0.179 & 0.106 & 1.687 & 0.101 & 0.391
\end{tabular}

\section{Notes:}

The reported explanatory variables are included one-by-one in the regressions.

Simple conditioning information set: logarithm of initial income and schooling.

Full conditioning information set: simple set, plus inflation, black market premium, government size, trade openness, and indicators of civil liberties, revolutions and coups, political assassinations, bureaucratic efficiency, and corruption.

Structure-Activity $=\operatorname{Ln}$ (total value traded ratio / bank credit ratio).

Structure-Size $=$ Ln (market capitalization ratio / bank credit ratio).

Structure-Efficiency $=$ Ln (total value traded ratio * overhead costs).

Structure-Aggregate $=$ principal component of Structure 1, 2, 3 .

Structure-Regulatory $=$ Index of regulatory restrictions on commercial bank activities. 


\section{TABLE V}

Financial Structure, Interactions with Income and the Legal System, and Growth

Dependent Variable: Real Per Capita GDP Growth, 1980-95 ${ }^{1}$

\begin{tabular}{|c|c|c|c|c|c|c|c|c|}
\hline \multicolumn{3}{|c|}{ Structure and Income Per Capita ${ }^{2}$} & \multicolumn{3}{|c|}{ Structure and Shareholder Rights $^{3}$} & \multicolumn{3}{|c|}{ Structure and the Rule of Law ${ }^{4}$} \\
\hline $\begin{array}{l}\text { Explanatory } \\
\text { Variable }\end{array}$ & coefficient & D-value & \begin{tabular}{|l} 
Explanatory \\
Variable
\end{tabular} & coefficient & -value & \begin{tabular}{|l} 
Explanatory \\
Variable
\end{tabular} & coefficient & -value \\
\hline Structure-Activity & 1.910 & 0.465 & Structure-Activity & 0.148 & 0.844 & Structure-Activity & -0.121 & 0.811 \\
\hline Structure-Activity*Income & -0.172 & 0.583 & Structure-Activity*Rights & 0.137 & 0.561 & Structure-Activity*Law & 0.130 & 0.341 \\
\hline Structure-Size & -2.102 & 0.235 & Structure-Size & -0.439 & 0.587 & Structure-Size & -0.895 & 0.177 \\
\hline Structure-Size*Income & 0.215 & 0.284 & Structure-Size*Rights & -0.078 & 0.806 & Structure-Size*Law & 0.147 & 0.286 \\
\hline Structure-Efficiency & 2.415 & 0.190 & Structure-Efficiency & 0.575 & 0.238 & Structure-Efficiency & 0.447 & 0.314 \\
\hline Structure-Efficiency*Income & -0.243 & 0.252 & Structure-Efficiency*Rights & -0.108 & 0.515 & Structure-Efficiency*Law & -0.035 & 0.757 \\
\hline Structure-Aggregate & 0.621 & 0.237 & Structure-Aggregate & 0.508 & 0.519 & Structure-Aggregate & -0.064 & 0.905 \\
\hline Structure-Aggregate*Income & -0.196 & 0.595 & Structure-Aggregate*Rights & -0.077 & 0.752 & Structure-Aggregate*Law & 0.089 & 0.517 \\
\hline Structure-Regulatory & -0.257 & 0.842 & Structure-Regulatory & -0.226 & 0.272 & Structure-Regulatory & -0.215 & 0.530 \\
\hline Structure-Regulatory*Income & 0.043 & 0.761 & Structure-Regulatory ${ }^{*}$ Rights & 0.112 & 0.058 & Structure-Regulatory*Law & 0.082 & 0.229 \\
\hline
\end{tabular}

\section{Notes:}

1. Each structure variable and the corresponding interaction term are included in separate regressions.

Thus, the table summarizes the results of 15 regressions.

2. Structure and income per capita regressions also include the logarithm of initial income and schooling.

3. Structure and shareholder rights regressions also include the logarithm of initial income and schooling, and Rights (which is an index of (equity) shareholc legal rights).

4. Structure and rule of law regressions also include the logarithm of initial income and schooling, and Law (which is an index of the degree to which the rule of law holds).

Structure-Activity = Ln (total value traded ratio / bank credit ratio).

Structure-Size $=\operatorname{Ln}$ (market capitalization ratio / bank credit ratio).

Structure-Efficiency $=\mathrm{Ln}$ (total value traded ratio * overhead costs).

Structure-Aggregate $=$ principal component of Structure 1, 2, 3.

Structure-Regulatory $=$ Index of regulatory restrictions on commercial bank activities.

Income $=$ Ln(Real per Capita GDP)

Rights = Index of (equity) shareholder rights.

Law $=$ Index of the degree to which the rule of law holds in a country. 


\section{TABLE VI}

Financial Development and Economic Growth

Dependent variable: Real per Capita GDP Growth, 1980-95

\section{Simple Conditioning Information Set}

\begin{tabular}{l|ccc|c|c}
$\begin{array}{l}\text { Explanatory } \\
\text { Variable }\end{array}$ & $\begin{array}{c}\text { coefficient } \\
\text { standard } \\
\text { error }\end{array}$ & \multicolumn{3}{c}{ t-statistic } & P-value $\begin{array}{c}\text { R- } \\
\text { Squared }\end{array}$ \\
\hline Finance-Activity & 0.645 & 0.170 & 3.792 & 0.001 & 0.316 \\
Finance-Size & 1.374 & 0.621 & 2.213 & 0.032 & 0.182 \\
Finance-Efficiency & 0.722 & 0.163 & 4.437 & 0.000 & 0.366 \\
Finance-Aggregate & 1.340 & 0.356 & 3.767 & 0.001 & 0.327
\end{tabular}

\section{Full Conditioning Information Set}

\begin{tabular}{l|ccc|c|c}
$\begin{array}{l}\text { Explanatory } \\
\text { Variable }\end{array}$ & $\begin{array}{c}\text { coefficient } \\
\text { standard } \\
\text { error }\end{array}$ & t-statistic & P-value & $\begin{array}{c}\text { R- } \\
\text { Squared }\end{array}$ \\
\hline Finance-Activity & 0.435 & 0.203 & 2.141 & 0.039 & 0.434 \\
Finance-Size & 0.371 & 0.684 & 0.542 & 0.591 & 0.360 \\
Finance-Efficiency & 0.527 & 0.215 & 2.450 & 0.019 & 0.464 \\
Finance-Aggregate & 0.897 & 0.407 & 2.204 & 0.034 & 0.425 \\
\hline
\end{tabular}

Notes:

The reported explanatory variables are included one-by-one in the regressions.

Simple conditioning information set: logarithm of initial income and schooling.

Full conditioning information set: simple set, plus inflation, black market premium, government size, trade openness, and indicators of civil liberties, revolutions and coups, political assassinations, bureaucratic efficiency, and corruption.

Finance-Activity $=\mathrm{Ln}$ (total value traded ratio * private credit ratio).

Finance-Size $=\operatorname{Ln}$ (market capitalization ratio + private credit ratio).

Finance-Efficiency $=\mathrm{Ln}$ (total value traded ratio / overhead costs).

Finance-Aggregate $=$ Principal component of Finance 1, 2, 3 . 


\section{TABLE VII}

Financial Development and Economic Growth, Instrumental Variables

Dependent variable: Real per Capita GDP Growth, 1980-95

\section{Simple Conditioning Information Set}

\begin{tabular}{|c|c|c|c|c|c|}
\hline $\begin{array}{l}\text { Explanatory } \\
\text { Variable }\end{array}$ & coefficient & $\begin{array}{l}\text { standard } \\
\text { error }\end{array}$ & t-stati & P-value & $\begin{array}{c}\mathrm{J}- \\
\text { Statistic }\end{array}$ \\
\hline Fina & 0.858 & 0.297 & 2.892 & 0.006 & 1.597 \\
\hline Fina & 1.704 & 0.566 & 3.010 & 0.005 & 1.299 \\
\hline Finar & 0.876 & 0.326 & 2.687 & 0.011 & 1.176 \\
\hline Finance-Aggregate & 1.418 & 0.478 & 2.965 & 0.005 & 1.412 \\
\hline
\end{tabular}

\section{Full Conditioning Information Set}

\begin{tabular}{l|ccc|c|c}
$\begin{array}{l}\text { Explanatory } \\
\text { Variable }\end{array}$ & \multicolumn{5}{c}{$\begin{array}{c}\text { coefficient } \\
\text { standard } \\
\text { error }\end{array}$} \\
\hline Finance-Actatistic & P-value & J- \\
Finance-Size & 1.132 & 0.518 & 2.183 & 0.038 & 0.311 \\
Finance-Efficiency & 3.039 & 1.372 & 2.214 & 0.035 & 1.183 \\
Finance-Aggregate & 0.861 & 0.311 & 2.769 & 0.010 & 0.561 \\
& 1.867 & 0.730 & 2.557 & 0.016 & 0.617 \\
\hline
\end{tabular}

Notes:

$\mathrm{N}^{*} \mathrm{~J}-S t a t i s t i c$ is distributed Chi-Squared with two degrees of freedom.

At the $10 \%$ level, the critical value is 4.61 . At the $5 \%$ level, the critical value is 5.99 .

The reported explanatory variables are included one-by-one in the regressions.

Simple conditioning information set: logarithm of initial income and schooling.

Full conditioning information set: simple set, plus inflation, black market premium, government size, trade openness, and indicators of civil liberties, revolutions and coups, political assassinations, bureaucratic efficiency, and corruption.

Instruments: creditor rights, shareholder rights, law and order

Finance-Activity $=\operatorname{Ln}$ (total value traded ratio * private credit ratio).

Finance-Size $=$ Ln (market capitalization ratio + private credit ratio).

Finance-Efficiency $=$ Ln (total value traded ratio / overhead costs).

Finance-Aggregate $=$ Principal component of Finance 1, 2, 3. 